\title{
PENGANTAR, OR INTRODUCTION TO NEW ORDER INDONESIA*
}

\author{
Saya Shiraishi
}

\section{Meeting People at the Airport}

Arrival without reception, departure without escort Datang tidak berjemput, pulang tidak berantar

This proverb is the first example given to illustrate the entries for both antar and jemput, in the Indonesian dictionary published by the Department of Culture and Education. ${ }^{1}$ Antar is to escort someone someplace, and jemput is to come to meet someone in order to escort him someplace else. The proverb literally means not doing either act, and thus indicates, according to the explanation which follows in the dictionary, that things are not being done the way they should be, in other words, the guest is not being treated properly.

The Soekarno-Hatta International Airport is located northwest of Jakarta, about one hour's drive from the center of the city by the toll roads. This new airport has brick-red tiled roofs and floors. The rosy red color of the tiles matches the first aerial view of Jakarta, which is of the numerous red tiled roofs which, half buried in voluptuous foliage, form a flat and vast island in the midst of an expansive sea of green rice fields. Here, in the former Dutch colonial capital, people built their houses with tiled roofs and whitewashed stone walls, and surrounded them with the thick shadows of the fast-growing tropical trees. The roof tiles were baked from the glaring sunset-red soil of the region which had once been called the Red Land. The deep eaves offered protection from the fierce equatorial sun and the massive rainfall. It is the color of Jakarta, or, rather, the color of the old elegant town of Batavia; the color of exotic charm and nostalgia as well as of security and comfort.

\footnotetext{
*I am grateful for the help I received from many people in writing this article. I would in particular like to express my appreciation to my husband, Takashi Shiraishi, for his support and understanding. For the article's shortcomings naturally I take sole responsibility.

${ }^{1}$ Departemen Pendidikan dan Kebudayaan, Tim Penysun Kamus Pusat Pembinaan dan Pengembangan Bahasa, Kamus Besar Bahasa Indonesia (Jakarta: Balai Pustaka, 1989), pp. 41, 357.
} 
Her initial few steps on the airport's tiled floor, however, alert the visitor that she has not only arrived on an exotic foreign soil, but has also left behind the familiar landscape in which none of the steps she took claimed her attention. The tiles of the floor are laid unevenly and covered by a slippery glassy layer, and the series of steps she has to take seem unexpectedly steep and narrow. Watch your step. This is the country, after all, whose regime proudly calls itself the New Order.

The customs counters are the last stage in the official procedures, and the visitor is there discharged with her luggage. Then, even before she can enjoy a moment of relief from official papers, she finds herself thrown into a vacant open space just outside the modern architectural structure, confronting, all by herself, hundreds of naked staring eyes. The throng, thickly gathered behind the high steel railings which run parallel to the dark glass walls of the airport building, is, for the arriving foreign visitors, the first encounter with the people, or rather with the idea of the little people - called rakyat -of Indonesia.

This four-foot wide space, left open between the glass walls and the railings behind which the crowd gathers, manifests the division of contemporary Indonesia. One half is the air-conditioned, high rise official world that is constructed with ruler-straight lines and right angles in which dark glass walls are in plentiful supply. From the inside a man can get a good view of the sun-bathed outside world, but from the outside, the inside of this official world is mysteriously dark, silent, and forbidding. The outer half is the world of the shapeless mass of the little people, whom the visitor is to meet now in the steaming heat.

The crowd behind the railing consists mostly of men clothed in the discolored gray or dull brown shirts and dark long trousers which, like a violent and yet accurate blow, cleanly do away with any expectation the visitor might have of meeting or seeing something tropical-the delightful breeze, pleasant transparent air, rich bright colors of abundant flowers in ever full bloom, and the trustful simple smiles of the noble people with their unhurried demeanor. Instead, the sight foretells the kind of colors she is to find in present-day Jakarta.

In spite of the commotion from the ebb and flow of people arriving and departing, a peculiar stony silence seems to lie among the persons who are standing behind the railing with their hands holding on to it. They form a silent shadowy mass, which, nonetheless, is not bound together, does not possess any comprehensible meaning through their presence together in this particular place at this specific moment. Each one has nothing to do with others standing around him. They are physically squeezed against the skins of the strangers who are standing so close to them. And yet, each man seems to have created his own invisible no man's land around himself which secures his aloneness among the crowd. The uneasy feeling of being touched by the strangers' skins and the persistent moist heat appear to have vaporously disappeared from his awareness. It is as if he is not really here underneath his skin.

Moreover, the crowd's reptile-like glassy stares are constantly fixed and refixed somewhere behind the shoulders of the approaching arrivals. All these visitors, who are unknown to them personally, do not exist in their eyes. Their stares keep focusing away from the visitors as if to erase their presence. These are not mere vacant spent gazes, either. There is some intensity and even an aura of intoxication. The crowd are where their stares are focused. They are where their anticipations lie. Where are they? Where is he?

Actually most of them are here, on a raised pavement in front of the airport building, waiting for hours without being provided any comfortable facilities, such as a waiting room with chairs and protecting walls, to meet their arriving guests, business associates, friends, relatives, or returning family members. They are the congregation of people who believe in 
and are in the service of performing the proper act in the way it should be carried out. They have come to meet their guests to escort them to their destinations.

A children's magazine portrays this airport experience from the other side of the railing. The following is part of a short story in which a grandfather is welcomed by his grandchildren at the domestic airline arrival gate. The scene describes fairly well the ritual of family meeting as I have experienced it countless times in Jakarta.

\section{Grandpa's Arrival}

Now Grandpa is coming to visit us. Mother and Kak [older sister] Tia have already prepared the room for Grandpa. I and Tino, my younger sister, are busy tidying up the garden in the back of the house. Weeds are cut out. It is important that the house should look tidy.

"Tika! Hurry up a little, we will be late!" shouts Kak Tia from the courtyard.

Today we are going to jemput Grandpa. I wear my dress with blue stripes and do not forget to arrange my hair in a pony-tail. Grandpa is particularly fond of pulling my pony-tail in his caressing. Trotting, I reach father's car which has already been started.

"Tika, you took a lot of time! Grandpa will be angry if he is kept waiting long," says Kak Tia with a frown.

"Sorry, Kak. Let's go now," I answer.

All the way I just kept silent, being absorbed with my own thoughts. Surely Grandpa must be fat by now. Because he can no longer be depressed. He sure will smile at Father, Mother, Tia and Tino, and of course at me, his favorite grandchild.

I was not aware that we had already arrived at the airport. The airplane carrying Grandpa had just landed. I busily looked for Grandpa. From that distance I examined intently each passenger who came off the airplane.

"Ah, Grandpa's taking a long time," I said anxiously.

"Just a while more, be patient," said Mother trying to soothe me.

"See, that's him! Hurray, Grandpa has come," exclaimed Tino.

"Where? Where is Grandpa?" I asked.

"There, with the brown batik shirt!" said Tino again.

"Oh, yes. Hey, my guess was right. Grandpa's gotten fat," I said with a smile.

We welcomed Grandpa. I was shocked for a moment. Grandpa's hair had turned white. But his body was fat, fatter than Father's. Father and Mother took turns to embrace Grandpa and kiss his hands. Kak Tia and Tino did the same.

"Tino, let me take my turn. You are taking too much time for your hugging," said I, impatient to embrace Grandpa to free longings I had held in my heart for over a year.

"Hey, here you are, the most naughty of all Grandpa's grandchildren. Already grown up tall."

I kept embracing and kissing Grandpa. Unaware of the small warm drops which flowed down my cheeks. I cried. I was very moved. I saw that Grandpa's eyes were also glistening. Apparently he had also been longing for us. ${ }^{2}$

This is the moment they have been waiting for. Here, now, this physical skin-to-skin contact between loving family members is the essential means of expressing their affection for each other. "I kept embracing and kissing Grandpa. I cried, I was very moved. I saw that Grandpa's eyes were also glistening." The old man arrives at the airport to encounter the crowd of strangers, whose eyes keep focusing away from him as if to erase his presence, if

2Theresia Mery, "Ketika Kakek Datang [When Grandpa Came]," Bobo 17 (August 6, 1988): 6-7. 
not his sense of existence, by their negative stares. He then finds his family members whose eyes meet his eyes and knot themselves with his, greeting him happily. He has found his own presence in his ties to his family who came to the airport solely to meet him. This is how a man finds himself and his place in Jakarta. This is how a man relates to the city of over eight million people, the city of over eight million strangers. His presence and identity are granted and assured in his embrace of his family. He is the Grandpa of this sweet little girl. There can be no doubt about it. He holds his own presence in his arms. It is warm, soft, and comforting beyond anything else. It is entirely different from those strangers' skins which, like reptiles', show no sign of caring or of warm response even when squeezed against each other.

I once saw an old mother being embraced and kissed by her son after months of separation. Over his shoulder, she gazed out through the lenses of her standing tears at the dark contained air of the front room in her house. Her intense emotion appeared to be concentrated in her fingertips, which were placed ever so softly around the neck of her son. It was as if both her hands had turned into fluffy feathers brought by a gentle breeze onto his shoulders. For his part, the young man, who could have displayed his emotional intensity by the physical strength of his muscular arms, was holding her narrow shoulders as tenderly as the faint reflection of the afternoon light in the room, his eyes refusing to meet anyone else, anything else, just to be here with his mother, only with his mother at this moment.

Toward sunset, now, everyday, I have to see my grandchildren. I need the warmth of the family atmosphere after being buried under my heavy workload. ${ }^{3}$

This is a paragraph which appeared in the recently published autobiography of President Soeharto. This short paragraph is inserted into the section which outlines his daily schedule. It is not only this two-sentence paragraph, but the meeting with his grandchildren that has to be inserted in his busy schedule. "now, every day, ... my grandchildren. I need the warmth of the family atmosphere...."

In this embrace, no exchange of spoken expressions of affection is required, or rather it is rejected at its height. It is not necessary for Tika, or for her grandfather, to tell the other with clarity and precision how much the other one has been missed. The mutuality of affection and longing is spelled out by the very absence of its verbal expression, and thus becomes, literally, a matter of course among the devoted family members.

So, that is where they are, the crowd in front of the airport. Their mind is already with their own people for whom they have come. All the other strangers around them or in front of them just do not exist in their eyes, or appear to be mere faceless obstructions.

The rest of the crowd behind the railing consists of those who seek their livelihood by picking at the arrivals who have nobody waiting for them. They will usher the newcomers to the pay-phone booths or to the taxi stand, which are both located only a few meters from the exit doors and are yet hidden and hindered by the thick crowd waiting for someone else. One has to pay for not being awaited, or for not arriving in the way one should.

When I arrived at the airport, my friend was not yet there. Considering all the arrangements that need to be satisfied before a car can take to the road, it is not uncommon for the dedicated pen-jemput (person who comes to pick up someone) not to appear on time. I

${ }^{3}$ G.Dwipayana and Ramadhan K.H., Soeharto: Pikiran, Ucapan, dan Tindakan Saya [Soeharto: My Thoughts, Speech, and Deeds], Otobiografi, seperti dipaparkan kepada G.Dwipayana dan Ramadhan K.H., (Jakarta: Citra Lamtoro Gung Persada, 1989), p.233. 
wanted to call his house, and found that I needed some 50 rupiah coins for the pay-phone. A man approached me at the booth and said that he had some coins. I thanked him and handed him two 100 rupiah bills. In return he gave me two 50 rupiah coins. After a call, I needed another coin or two. I looked for the only face I had come to recognize, ignoring all the others, and dragged my luggage toward him. I asked him for another coin and handed him two more 100 rupiah bills. He looked at me, searched his pockets, and gave me, this time, four 50 rupiah coins. Before I noticed what had happened (I am always too slow to notice things), he disappeared into the crowd of people. I needed the coins so much that I did not mind someone making such a small profit out of our transaction. The exchange rate then was roughly one dollar to 1,600 rupiah. I felt sorry for his not getting anything from the service he offered me the second time. Should I not have recognized him among other faceless strangers? Should I not have smiled at him happily when I found him?

\section{Visiting Friends, or How to Travel in Jakarta}

Most escorting, or jemput-antar, in Jakarta is conducted with a car. Once a young man said to me that a family that did not have a car in Jakarta would feel inadequate. A brief survey of the streets in Jakarta would easily confirm his statement. Some companies have special loan assistance programs for their employees to purchase private cars. A newspaper company lends its reporters new company-owned cars, which, after a few years of automatic deduction from their salaries, become their own property. More often, the old used company cars can be purchased at relatively cheap prices. Of course, the official use of company cars is most frequently the jemput-antar of the company's guests and executives.

There are also various ways a man can make use of the car that he does not own. One of the ways is to have the right to use a company car not only for the purpose of official business in its strict sense but also for his every transportation need, which includes the jemputantar of his family, friends, and relatives. Sometimes a man will ask his family or friends who own or have access to a car to escort him when he is to jemput-antar someone else. A singer borrowed the company car of his friend-producer when he needed to jemput-antar his visiting foreign friend.

The fantastic best-selling novel of the late 1970s, Arjuna Mencari Cinta [Arjuna's quest for love], starts with the incident that deprived Arjuna, a high-school kid belonging to a newly rich Jakarta family, of his free use of the mobil dinas (official office-owned car) of his father. Arjuna is the name of a hero of the Javanese shadow-play who is an "unequalled warrior on the battlefield," whose "amorous adventures never cease to delight the Javanese." 4 In this novel the shadow-play heroes, who once traversed the dark vast imaginative universe of the Javanese, now race their VWs, Volvos, or their father's official cars on the streets of Jakarta as "privileged adolescents," 5 with their schoolmate-girlfriends accompanying them in the place of heavenly princesses.

One rousing morning, Arjuna stood with his arms akimbo. He felt depressed and irritated. The previous evening his Papi [Coll. father] had flown into a rage when he spotted that kid [anak] of his necking with a girl in his official car.

"The child [Anak] knows no rules [aturan]! Who is the girl?!" he scolded.

\footnotetext{
${ }^{4}$ Benedict R. O'G. Anderson, Mythology and the Tolerance of the Javanese (Ithaca: Cornell Modern Indonesia Project, 1965), p. 13.

${ }^{5}$ Savitri Scherer, "Yudhistira Ardi Noegraha: Social Attitudes in the Works of a Popular Writer," Indonesia 31 (April 1981): 35.
} 
"Oh, one of my sweethearts," answered Arjuna resentfully, feeling that his personal life was being meddled with.

"One of your sweethearts? One of?!" Papi's eyeballs bulged. Last night. And Arjuna got more and more fed up with Papi's attitude.

And this morning, Arjuna becomes more and more annoyed because he is not allowed to use the official car any more, whereas in fact that car has been his vehicle up till now. Arjuna likes that car because that kind of official Toyota possesses authority. Besides that, if you go everywhere in an office car you save a lot: all you have to do is pick up the gas from the office and you can get them to pay for repairs, large or small, too.

Arjuna does not want to get a headache worrying whether Papi's office will go bankrupt because of this sort of rip-off. He simply thinks: Papi's office cannot go bankrupt, since it is government property; after all, isn't our government very rich, with lots of money? The proof is: no matter how much of its money and property are embezzled and stolen, the government still keeps going and is still able to develop!6

The separation between the official world and the little people, which appears to be hopelessly, and therefore hopefully, decisive in front of the airport building is, thus, intricately intertwined and fused at the other end. Behind the waiting crowd at the airport is the large parking lot where the cars that have brought them are parked. Some of these are their privately owned cars, some are their company owned official cars, their friends' company cars, or their family's (father's, or younger brother's wife's brother's) official cars. I once saw a white ambulance in the service of an overnight family trip from Jakarta to Solo, Central Java.

Arjuna eventually falls in love with his father's secretary. In their rather longish telephone conversation, the seductive secretary laments,

Your Papi is supervising me more strictly than before. I may not speak long over the telephone, and I am not allowed to go out of the building before office hours are over![!]

Obviously she has been accustomed to do both. Eventually, as the official Toyota, which is owned and whose maintenance expenses are paid by the office, is placed under the full command of Arjuna's father, the secretary, whose salary is paid by the office, is found, before Arjuna's eyes, sprawling under his father.

Arjuna saw his Pergiwati being embraced by his Papi. Pergiwati whom he had yearned for and loved so deeply was now devoured by his Papi whom he had lately come to hate intensely.

And they were apparently so pleasantly occupied that they did not realize that there was someone else in the room who was watching what they were doing with full resentment [dendam], anger, pain, jealousy, sorrow, and other feelings which would have caused a person with weak mentality to lose his footing. ${ }^{8}$

\footnotetext{
${ }^{6}$ Yudhistira Ardi Noegraha, Arjuna Mencari Cinta [Arjuna's quest for love] (Jakarta: Cypress, 1977), pp. 7-8. My translation is based in part on that in Benedict R. Anderson, "Sembah-Sumpah [Courtesy and Curses]: The Politics of Language and Javanese Culture," in Change and Continuity in Southeast Asia, ed. Roger A. Long and Damaris A. Kirchhofer, The Papers of the Distinguished Scholars Series, University of Hawaii, 1982, Southeast Asia Paper No. 23, Southeast Asian Studies, Center for Asian and Pacific Studies (Manoa: University of Hawaii, 1984), pp. 38-39; and in Savitri Scherer, "Yudhistira Ardi Noegraha," p. 37.

${ }^{7}$ Yudhistira Ardi Noegraha, Arjuna mencari cinta, p. 181.

${ }^{8}$ Ibid., p. 185.
} 
The story ends with Arjuna:

Bellowing out the curses that had earlier exploded from Papi's mouth when he'd caught Arjuna kissing Pergiwati's lips in this very same room.

"You really have no manners [kurang-ajar]! Damn! You know no rules [aturan] Satan!

Goat! Horse! Cow! Water buffalo, and their accomplices!!!" he cursed. Then Arjuna spat. Fuih!! 9

It is not only at the readers' faces ${ }^{10}$ but also at the father who monopolizes ajaran and aturan, at the person who controls the use of the official Toyota which he does not own, and at the person who controls the secretary's life both official and private, that Arjuna spits. It is against the person who holds in his hands the authority to claim ajaran and aturan as his own, as well as the free use of the official Toyota and the office secretary, that Arjuna returns the curse which had once been thrown at him.

The right to use the official Toyota is attributed to the office Arjuna's father holds. "Arjuna likes that car because that kind of official Toyota possesses authority." The private use of the official car displays free personal access to official property. "Isn't our government very rich, with lots of money? The proof is: no matter how much of its money and property are embezzled and stolen, the government still keeps going and is still able to develop!" With the revenue from oil and foreign aid for development, the government and its offices have been the largest, richest, and bottomless sources of national wealth in Indonesia. A privately owned car means nothing more than the possesion of a car, the luster of whose paint and whose value will decrease in time. While on the other hand, the free access to official property, which the official Toyota demonstrates on the streets, means a hand on the tap controlling the flow of milk and honey. No wonder aturan, the word is closely associated with regulating a flow of liquid-like movement, is captured and manipulated by the same hand.

Suppose there were no feeling of love arising in his soul, which rages so, of course he would not feel so betrayed [di-khianati] by Pergiwati. Also by his Papi.

Suppose there were no power that is so great in the hands of his Papi, suppose there were no manners [ajaran] that compel children to respect and be loyal to their parents, there would of course be no such great turmoil in Arjuna's soul. ${ }^{11}$

The Javanese hero, who was "a splended warrior riding to war in a glittering chariot"12 in its heavenly landscape, is now entrapped within the web of personal authority, as well as within the web of the congested streets of New Order Jakarta. Once out of favor with his father as one who knows no aturan, Arjuna is out of his official Toyota chariot. In order to traverse the streets of Jakarta, Arjuna has to comply with his father's wishes as much as he has to observe the traffic regulations, or aturan.

Let us now go out to the street to see what actually happens there, and how.

Eko and I were invited to a party, which we were told would begin at six o'clock. I was ready at five o'clock at Eko's house. Eko came back from work at a little before six. We had to wait until six thirty for his brother, Anto, who arrived with a car, a shiny white Honda, which would take us to the party. After ten minutes of driving, however,

\footnotetext{
9lbid., p. 186.

${ }^{10}$ Anderson, "Sembah-Sumpah," p. 42.

${ }^{11}$ Yudhistira ANM Massardi, Arjuna mencari cinta Part II (Arjuna Drops Out) Jakarta: Cypress, 1980), p. 14.

${ }^{12}$ Scherer, "Yudhistira Ardi Noegraha," p. 39.
} 
our car stopped at the house of the wife of another of their brothers, Endi, where, in due course, we were invited to come in, take seats, and drink glasses of tea.

Endi's wife, Dewi, meanwhile, politely asked our permission to retire to her room to prepare for the party. At this point, I learned that the car belonged to her family, and Eko had invited Endi and Dewi to go to the party with us. She took a bath, changed her dress, and carefully made up her face, as if donning armor. We left there at seven thirty.

Eko smiled at me and said soothingly (he can be very charming in these instances) that no party begins at six in Jakarta. If we get there at eight that will be just fine. It turned out that none of us, five people by then, knew the exact location of the house we were invited to go to. It was almost nine o'clock when we finally reached our host's house. The party had started at seven thirty.

When a car is to take to the road, certain human relationships have to be worked out. I was escorted to the party in the white Honda because I was a friend of Eko. Eko had access to the car because he was the older brother of Endi, who, in turn, had access to it because of his wife, who was the sister of the owner of the car (or was the car owned by his company?). Thus, once on the road, the car starts to weave this network of human relationships which actually appear to be a sequence of jemput and antar among those participating in the journey.

On another occasion, I found myself in the white Honda with the two brothers, Eko and Endi, their old mother, and their wives. We were on the way back from a theater, where we had enjoyed watching a play together. It was the opening night and the play lasted longer than usual. We were all tired when we left the theater around midnight. Their ordinarily vivacious and shrewd mother was seated with her mouth tightly closed and her body fastened to the seat as if she had turned into an inanimate object which, however, was capable of imagining itself being moved by invisible hands from one place to another.

For the first time in our numerous outings together, the brothers discussed, in low, quick voices, which route to take, that is to say, who should be brought back to his/her house first and who should be next. It was always their mother who received priority. There was no need for any discussion or suggestion. But that night, Dewi was anxious to return to their sick child, and Eko's wife was pregnant and she had a previous history of miscarriages. They also had a foreign guest in the back seat of their Honda, who had little idea of her whereabouts in this enormous city and was already lost in the intricate web of human relations manifested inside the car. As usual, they brought their mother home first, but she apparently sensed the threat to the unquestioned priority that she had previously enjoyed. The fact that a discussion even took place between her sons was perhaps significant enough. Next morning the mother complained to me of the habit of heavy smoking of her young daughters-in-law, pointing out its unfavorable effects on their child and unborn baby, as well as its daily cost that their husbands had to meet, of about 800 rupiah a day by her calculation.

She knew what was at stake that night. There always seems to exist an invisible routemap for the car that is to jemput-antar more than two persons. The route-map is devised not only from the geographical locations of the houses of the participants, but also from the relative positions they occupy in the abstract complex of interrelationships.

In the case of the crowd I encountered in front of the airport, there were no relationships among them. Though most of them shared a common purpose in being there, which was to jemput-antar their guests, they were gathered together there by mere chance. Their shared purpose was to pick out and distinguish their own folk from all the other faceless strangers. 
There was no shared sympathy among them. They had nothing to do with the strangers around them who did not even exist in their eyes.

On the other hand, in this small space within the car, each member of the party had his/her specific relationship with the other members. The social hierarchy, family relations, sex, degree of intimacy and familiarity, need of protection, and all sorts of personal conditions were counted and respected. Being an Indonesian in Jakarta requires being capable of taking into account all the intricate human relations, and then, accordingly, reorganizing the streets into a sequence of jemput-antar route-maps that every participant of the excursion accepts and feels to have been properly respected. A car runs along the streets of Jakarta, back and forth, round and round, tracing, manifesting, expanding, and asserting the otherwise invisible, inarticulate human relationships.

The streets in Jakarta are jammed with thousands of cars from early morning to very late at night. They run around the streets so close to each other and yet never meeting, though they may bump into one another, thus resembling in appearance a crowd of strangers flooding over the streets. In this sea of strangers, each car pursues its own imagined routemap that connects families, relatives, and friends as well as business contacts. (Any official relationships tend to dissolve into the network of human relations.) It is this route-map, not the glossy color-printed street maps tourists buy at bookstores, that is the Jakarta in which people live.

\section{A Robber and a Pickpocket}

Aha, this is the one! He thought while stealing a glance at the seat next to his. An innocent-looking plain girl. Her hair is arranged in a way that emphasizes the point. ${ }^{13}$

In the best-selling children's weekly magazine that is distributed in the elementary schools and by newspaper delivery boys, as well as at the numerous sidewalk book stands, a bank robber rides a train to escape from the pursuing policemen. He has already made the error of not having his friend or family waiting for him in front of the bank with a car. He is forced to take public transportation, in this case a train.

In five minutes the train will reach the next station. The moments of strain! The police must be already waiting for him there. But this girl ... I can make her a hostage! That is his thought. ${ }^{14}$

The girl who sits beside him in the train is a stranger to him, as all the other passengers are in such public transportation. He, nonetheless, forms the opinion that she is an innocent plain girl who will make an easy hostage.

At that moment Mr. Robber is startled. He sharply eyed the girl. And he is really astonished when he searches his jacket pocket. His pistol has vanished! In the meantime, the girl smiled sarcastically while pointing a pistol at him. Ya, the pistol owned by $\mathrm{Mr}$. Robber has already changed hands! Apparently, she has made good use of the plot of the story she has just read to outwit Mr. Robber. Although she is not one of the pickpockets! She thought, however, that there is nothing wrong with imitating their methods in order to save her own life!

${ }^{13}$ Yutha D., "Perampok dan Pencopet [A robber and a pickpocket]," Bobo 22 (September 10, 1988): 8.

${ }^{14}$ Ibid. 
And when the train arrived at the next station, the girl handed the robber over to the police. Afterwards she proceeded to the campus alone. She attends classes in the Law Department of a famous university. ${ }^{15}$

Any stranger is a potential pickpocket, who will steal one's valuables. The children's short story illustrates the danger prevailing outside the protective network of friends and families. Even the bank robber, who has also committed a murder with the pistol he is carrying in his pocket, is vulnerable to the danger that strangers pose in any public place, such as trains, buses, markets, and streets.

"Public"? Can it still be called "public" transportation if all the fellow passengers are pickpockets, or regarded as potential pickpockets with the inherent faculty of performing the act whenever the opportunity arises? In a TV program dealing with the potential of tourism in Jakarta, a young Australian tourist complained that on his first day in Jakarta he was robbed by a group on a crowded public street in daylight, and no one came forward to help him, nor were the pickpockets afraid of the crowd standing around them.

The crowd [orang banyak. Lit. many people] in the street are simply large numbers of unacquainted persons without any specific human relationship that connects one to the other. They are many strangers. The strangers who are present everywhere in Jakarta, in front of the airport, in the trains and buses, and on the streets. And yet they are invisible because they do not exist in the eyes of the beholders, who are only looking for the faces familiar to them. Little wonder that strangers, who are invisible men, are capable of becoming astute pickpockets.

There are streets crowded with strangers who are all, thus, latent pickpockets, but there is no "public" street governed by public order. That is precisely the lesson taught by the children's stories.

\section{One Afternoon in the Bus}

The heat of the sun feels parching. Reni fans herself with her handkerchief. Every now and then she sighs. Every now and then she wipes off her sweat. In the meantime several buses for Manggarai via Block $M$ have already passed. But she has not yet dared to step into the bus. Because just as the bus stops, the passengers struggle to step on or off, pushing or jostling each other. That has made Reni reluctant to step on.

She does not want to be squeezed among the people's jostling bodies. Besides, she has heard stories that in just such moments of pushing and jostling the pickpockets like to take action. Wah! The money for the school fees in her bag could fly away. ${ }^{16}$

This account describes the sun-roasted bus stop in Jakarta. Reni is standing there enduring the heat. The parching heat of the sun in this passage indicates not only the equatorial location of the city on our dear blue earth, but also Reni's highly susceptible condition on a street of the city. She is exposed to the full force of its climate.

"Uh," she moaned in her heart. Enviously she looked at the cars which were passing along the street. How happy she would be if she were to go to school by car. Let alone if the car were air-conditioned. ${ }^{17}$

\footnotetext{
${ }^{15}$ Ibid., p. 9.

16Kemala P., "Suatu Siang di atas Bus [One afternoon in a bus]," Bobo 25 (October 1, 1988): 20.

${ }^{17}$ Ibid.
} 
This is an open-handed, matter-of-fact way of commending the comfort the air-conditioned car promises. It is the comfort that jemput-antar by family (or office) car provides; it is the comfort that jemput-antar furnishes of being protected on the street. Not provided with this protection, Reni suffers the parching heat of the sun, which indicates her high vulnerability to the dangers of the street. She is exposed, alone. The danger eventually manifests itself as a pickpocket who successfully takes her school money away.

The young readers should anticipate this after the very first sentence of the story: "The heat of the sun feels parching." instead of "The sun over the mountain illuminates my house, dries our clothes, and, with its rays, keeps my family always healthy."18 It is the sign of impending calamity. As a result, Reni is standing at the bus stop entrenched in her apprehension, incapable of taking her own steps.

\section{Susi, Grandpa's Grandchild}

Susi laughed. Actually in her heart Susi is very much annoyed. Her classmates are all jemput-antar-ed by their mothers, nurses, chauffeurs, or maids. It is Susi alone who is jemput-antar-ed by her grandfather. Susi's father and mother have to go to the hospital very early in the morning, because they both are doctors. It is often evening, or even sometimes late at night before they come back home. For this reason Susi spends more time with her grandfather and grandmother.

A short fat-bodied old man with a bald head is standing outside the gateway to the school among all the other pen-jemput [persons who jemput]. His eyes looking for Susi, his dear granddaughter.

When he finds Susi who is walking toward him in front of her friends, the old man smiles. Thus, when Susi comes close to him, he holds her hand. They go back to his old car.

"It is so hot, Grandpa!" says Susi. "I'm thirsty!"

"Don't worry. There you see in the car the bottle of cold orange juice Grandma prepared!" answers Grandfather. Susi's eyes shine. Oh, how happy she is! How nice Grandpa and Grandma are!19

Susi is the girl who passes in her grandfather's car by the bus stop where Reni is waiting for her bus. Susi is the girl whom Reni envies. The deliciousness of the passage, with the taste of cold orange juice, arises out of the family affection and happiness, which the scene of the jemput-antar of school children has manifested. The jemput-antar/protection is an expression of Susi's grandparents' affection toward their dear granddaughter.

This adored and spoiled girl has to undergo a punishment, therefore, when she rejects the privileged protection provided by her loving grandfather.

The next morning Susi gets up very early. She leaves for school, highspirited, with Bik Tarni, the maid. Grandfather and Grandmother give instructions to Dik Tarni again and again to be very careful. ${ }^{20}$

Susi is full of spirit this morning because she is going to do what she has wished to do and what she herself has decided to do. The little girl is trying to assert herself. She does not want to be identified merely as the dear little granddaughter of the old bald man.

\footnotetext{
${ }^{18}$ Esthy M. W., Tuhan pencipta [God that creates], Seri Bidang PMP di TK 1 (Semarang: Mandira, 1987), p. 5.

${ }^{19}$ Widya Suwarna, "Susi, Cucu Kakek [Susi, grandpa's grandchild]," Bobo 22 (September 10, 1988): 32.

$20_{\text {Ibid., p. } 33 .}$
} 
They [Susi and Bik Tarni] have already waited a long time, but the bus they are waiting for does not come. Susi feels tired and thirsty. She squats on the bus stop platform. She reflects on the ease and comfort she has enjoyed in the car with her grandfather. ${ }^{21}$

And now she is punished for her impertinence. Had she accepted the easy comfort her family had offered her, unquestioningly, or nonchalantly as Arjuna had accepted his father's official Toyota, she would not have had to go through the exhaustion and thirst at the busstop. She has misbehaved by deviating from the correct mode of behavior. She should have accepted the protection her family furnished for her, with a little bit more appreciation. And she will, from now on.

"Noooh! Susi wants to go to school with Grandpa only. Didn't you say, Grandpa, that you would never be tired of doing antar for Susi?" says Susi laughing. Grandfather and Bik Tarni are laughing too. 22

The reality of the streets in Jakarta, the heat and danger, was too severe and unsparing for a little girl to take a stand for independence from her family's caring grip. Without it, the children's stories tell the readers, a little child would be roasted and have her pocket picked. Susi has learned this now. Susi happily accepts being the adored, well-cared-for grandchild of her grandfather by accepting the comfort and protection he provides for his grandchild. Rejection of the protection implies refusing to accept the affectionate relationship that ties her with her grandfather. She remains "Grandpa's grandchild" - because of the heat on the streets.

Is this the true reality of the streets? Is the heat of the Jakarta streets so bad? Let me reflect here for a moment, as Susi did at the bus-stop, not on the comfort of the car, however, but on the parching heat of the streets.

Apparently the streets in contemporary Jakarta are not meant for pedestrians. The wide and well-tended main roads, with all the center-green strips, statues, monuments, waterfountains, and shade trees, do not provide enough safe crossings for pedestrians. And the streets are always flooded by numerous cars. Every car in this city may be very well utilized every day transporting its owner, his family, his in-laws, their friends, and guests. The sidewalks are either invaded by motorcycles, or constructed as side-platforms, raised as much as a foot above street level. As a result, a pedestrian has to go through an endless series of stepping down and up at each house gate and each entrance or exit driveway of the buildings standing in rows along the street.

This sidewalk is, however, a perfect place for peddlers to spread out their merchandise, to establish unmarked bases, or just to rest for a while. A recent article in an adults' weekly magazine featured "Sweeping off all the hawkers" from the streets of the capital city. The article attempted to speculate on their numbers in the following manner.

He really keeps track of the world of the street hawkers. And he has data. In his record, half of 830 intersections in Jakarta which have traffic lights are the bases for these street peddlers. Each [base] has an average of 20 peddlers tending their business there. If this number were accurate the street peddlers in the capital city would number $8,300.23$

\footnotetext{
${ }^{21}$ Ibid.

${ }^{22}$ Ibid.

${ }^{23}$ Zaim Uchrowi, Linda Djalil, Rustam F. Mandayun, "Menyapu para Pedagang Asongan (Sweeping off all the hawkers)," Tempo 32 (October 7, 1989): 53.
} 
The article also contains several excellent photographs of the familiar sights of the carcongested streets and the young crafty street merchants brightly beaming at the camera. They range from 7 or 8 year-old boy singers to teenage cigarette sellers. They belong to the same age group as Susi and Reni, and yet they look less affected by the heat and they look rather immune to pickpockets. Here I am not going to say that their daily business on the streets is easy. Many people are very much concerned about the welfare and safety of these children. But it is also true that their youthful ingenuity casually surpasses the compassion foreign visitors are prepared to offer them.

A middle-aged peasant I met in a small mountainside village in Pekalongan, Central Java, said that his daily back-breaking labor in the muddy terraced rice fields was harsher than his experience as a peddler on the streets in Jakarta. The heat? The sun? The rain? I was born here, in this land. He smiled one of these patient smiles. I am used to them (sudah biasa). It was the cars and the traffic accidents that he did not like while he was there, on the streets of Jakarta.

Some young urban children can be found who are even tougher than the hardened peasants on the streets of their home city. It was a holiday afternoon. I watched a group of children playing on a sidewalk at the corner of a busy intersection. Each child was to choose one of the two vaguely fixed spots on the sidewalk where a bus would stop if the traffic light was red. Two children at one spot vs. three at the other, for example. Most buses are not air-conditioned; therefore, both their front and back doors are always kept open. The bus conductor stands by one of the two doors when the bus comes to a halt. If the conductor is found guarding the back door, the two children who have waited for this chance at the front spot, jump into the front door of the bus, run through the center aisle toward the conductor guarded back door, jump off the back of the bus, pushing the conductor aside and landing back on the sidewalk exactly in front of the three children whom the conductor is preventing from getting on the bus. The conductor can stop the children getting on the bus, but he does not dare prevent the children already on the bus from jumping out through the back door. Because he has to get rid of them before the light turns green and the bus starts moving again. His shout after the two children only enhances their triumph over the three who picked the wrong end.

They were tireless, and indifferent to the heat of the afternoon streets. They were not afraid of pickpockets, not afraid of the moving bus. They were not even afraid of pushing the angry conductor aside. They had made their logical calculations and also had experimental understanding that the responsive behavior of the conductor would not fail them. I was also amazed that watching them play this potentially dangerous game did not cause any anxiety to me who have two sons of their age. It was partly because their movements had such dashing agility, and it was also because I saw the bus driver looking carefully into the mirror to make sure that the children were safely off the bus before he started off again at the green light. It was not the only time I experienced the way people care for the children, for the children with whom they have no personal relationships at all, for even the children who are in their way. After a while they moved on to the next intersection and continued the game.

The heat on the streets of Jakarta is not essentially as severe as arctic cold which denies survival to an unprotected human body. The equatorial heat in this city of the archipelago allows a variety of responses. For example, a man may wrap his body from head to toe to protect his body from the sun. Alternatively, he may completely unwrap the clothes from his body to enjoy the breeze, the sunlight, and free unobstructed bodily movements. Any style between the two extremes is also possible. Likewise, a man can build an open, air-cir- 
culating wooden house, which is the style of most of the traditional houses in the archipelago, or a thick stone-walled heavily protective house, which is the basic trend of the houses in Jakarta. In other words, the same climate can cause a man to clothe himself as much as to unclothe himself. The sun's heat on the Jakarta streets is indeed intense. Nonetheless, it is still open for imaginative human beings to interpret and perceive the heat in varied ways.

The literary expression of the sun as "parching" is thus one of varicolored possible ways of facing the climate on the streets, and is never the only mode available to us. It is, however, the way which is consistent with perceiving Jakarta as a place that needs stone houses with high barbed-wire fences, air-conditioned cars, leather jackets, socks, and shoes. (Taking them off upon returning to one's house has become a moment of delightful sensual pleasure, and whether the wife should help her husband take them off, or should not, has been debated in modern Indonesian literature concerned with women's liberation. One of the answers I found in a children's picture book was a younger brother helping his sister change her shoes for sandals. ${ }^{24}$ )

In contrast to the car-flooded streets, the sidewalks in front of these high fenced and stone-walled houses are mostly abandoned, except for occasional peddlers and the inevitable gate-guards. The only pedestrians who can be found walking along the main streets are foreign tourists. And this is something that the Jakartans do not understand. Foreign tourists are regarded as peculiar kinds of people who walk! along the streets and take buses even though they are carrying money!

On one occasion, the car driven by my friend passed by a young Western tourist with his backpack, walking on a sidewalk along a busy street. "It's hot," my friend said. Our car was well air-conditioned. "These Western tourists, they always walk. They do not have cars. They do not have friends. Pity!"

In another case, there was a group of Western tourists walking on a sidewalk, who stopped to discuss something at the corner of an intersection. Some apparently wanted to cross the street, some wanted to venture into the side street, and some were in favor of keeping walking straight along the main street. When we saw them from our car, stopped at a red light, my companion then said, "Bewildered [Bingung] they are." The following is an account of the situation we were in when we found the tourist group.

This time I was invited for a children's painting contest in which my multi-talented friend was a judge. She drives her (company) car every day to her office, to the elementary school where she teaches painting, and to these various programs. She ordinarily is a competent driver, who knows her way around the city well.

However, that day her husband sat next to her in the passenger seat, and at the first main intersection he told her curtly, "Left!" She usually takes the direct route that goes by the school where she teaches, in order to go to the northern section of the city where we were headed that day. He had a different route in his mind, and she amenably steered the wheel to the left.

As a consequence of this left turn, and because he never formulated fully in any systematic way the route we were to take, at each approaching intersection she had to ask or wait for him to tell her whether she was to drive straight, right, or left. She was trans-

${ }^{24}$ Ibu Esthi M.W., Mengucap Terima Kasih [Saying thank you], seri bidang PMP di TK, (Semarang: Mandira, 1988), p. 7 . 
formed from a highly educated, inspiring woman into an obedient, awkward driver who was not sure of the direction she was taking.

It was then at an intersection that we saw the tourist group. Each of the tourists had her own idea as to which direction to take and none displayed a personality likely to be amenable to others' desires. It was a group in which each member maintained equal standing and voice. There was no single person to tell the whole group, "Left!" It was a group lacking the hierarchical order that is expected to be intrinsically present in Jakarta among any group of people who are not strangers to each other.

"Bewildered" was the statement made by my friend's husband, who saw them discussing their decision as to which direction to take as a group at the street corner. It was a "bewilderment" which emerged out of the unorderly confusion of this basic group formation. They were obviously a peculiar group of people to be seen on a street of this Republic's capital city. The word spat out of his mouth implied that the group did not belong to the place. I have also come to think now, a year since this small incident, that it was also the exposure of in-group conflict which drew stares from strangers on the street and led to his verbal denunciation.

In total defiance of all this passing ridicule, Western tourists, with cameras dangling from their necks, walk and walk along the busy streets, incessantly climbing down and up, down and up, on the series of sidewalks in search of exotic culture. The sun may try to beat them down on the streets, but they are fully equipped for a tropical land, or for an extra summer. A young Western couple may be spotted with their shorts, T-shirts and/or tank tops, open-toe flat sandals, complete with brimmed hats and sun-glasses.

In the eyes of Jakartans they are walking manifestations of exposure. Exposure to the sun, to the danger of the streets, that is to the pickpocket, as well as to the eyes of strangers. They are doubly exposed, because they appear to be without any protective blanket of personal human relations or official institutions that could have provided them with the service of jemput-antar by an air-conditioned car, the practice which the Westerners living in Jakarta quickly adopt. Walking on the streets indicates no access to a car/protection. No access to anybody, anywhere. What they carry on them is all that they have.

The Jakartans in their passing cars, on the other hand, incessantly run around the city, back and forth, round and round, busily tracing the imagined network which they conceive as orderly human relations tied by affection and respect. That is precisely the cultural activity the foreign tourists, including myself, have come here to see. I took tens of dozens of pictures of the streets, of the cars that overflow the streets, as if taking pictures of Javanese dances or shadow plays. The Jakartans in quest of love. Street-watching became my addictive habit, fascinating me so much that I can not imagine this fantastic city without its bizarre streets.

We may, nevertheless, take a rest now inside a house and its courtyard, where the interlacing relationships also take a rest and the knots are re-tied.

\section{Air-Conditioned Courtyards}

Let me present here a fascinating story that I heard personally in this exotic city.

The first evening in Jakarta in my friend Anto's house I asked about his nephew, who was born the previous year. With Anto's mother nodding in agreement beside us, he told me the following story. 
His nephew was born in an air-conditioned hospital and brought back to his large spacious air-conditioned house in an air-conditioned car. He has been brought up in the air-conditioned house since then, and whenever, wherever he goes out, he is transported in the air-conditioned car. As a result, if he is taken out of the house, out of the car, being exposed to the outdoor climate, he starts crying because he can not endure the sun's heat, nor the direct sun's rays. What would it be like to grow up without knowing how to accommodate to the natural climate of his motherland?

At this point, both Anto and his mother showed apprehensive concern on their faces for the future of the little boy. I was quite taken aback. "Even in the courtyard of his house?" I asked. "Yeah, sure." He was not so sure.

The next weekend the little boy came to visit his grandmother with his parents in their air-conditioned car, as they usually do almost every weekend. I was curious to see the behavior of the boy, because his grandmother's house where I was staying did not have airconditioning.

He is perfectly happy and excitedly moves around both inside the house and in the courtyard! He knows that all the attention of the household members is focused on him, follows after him. He is on stage. His toys are not utilized to amuse himself. They are turned into theatrical tools with which he stirs agitation and laughter among the adults who are eager to be entertained.

Having him as the core of the affectionate ties of the family members, relatives, and household helpers, their network of relationships seemed to have been completed. Everyone gathers around him to please him and to be pleased by him. On this luxuriously idle Sunday morning, there has come into existence a small cosmos, an ordered, harmonious, and whole system, in the small courtyard of a house at the corner of a densely populated section of Jakarta. All of the participants have come to be related to the others for their own unique and varied reasons. Once inside this enclosed courtyard of the house (halaman rumah), even the anthropologist with the foreign passport was not regarded as an alien anymore. She is naturalized in this courtyard cosmos as is. There could be hundreds of cosmoses to be found in that neighborhood alone. There provably is one also in the household of President Soeharto.

The boy was exposed to the sun's heat and the sun's rays, about which he could not care less. And yet he was followed by a uniformed nurse like a white shadow who kept cold drinks and soft baby snacks ready at hand, and was always prepared to carry the boy on her hip at the tiniest hint of weariness. He was not allowed to feel thirst, hunger, or physical exhaustion. The extraordinary story of the life of this little boy was even more real than the apparent reality. The air-conditioned enclosure in which, I had been told, the boy was brought up was the sign of this thickly protective blanket he was accustomed to take for granted. The courtyard of his house, or that of his grandmother's house, may not be actually air-conditioned. But they are as thickly protected and enclosed against the outside climate as any air-conditoned enclosures are. He will soon be jemput-antar-ed to his schools, like the little grandchild Susi, and eventually be given a car for his own use, like the high school kid Arjuna.

In this cosmos, the names of the rules are sopan santun (good respectful correct manners) on the part of the children, and kasih-sayang (affection) on the part of the parents and grand- 
parents. ${ }^{25}$ Here every member knows who he is and calmly assumes that every other member accepts who he is. A certain set pattern of behavior among its members is expected to be observed. Here anthropologists may find the familiar sphere where certain fixed cultural values and behaviors seem to be still functioning, and therefore can be isolated as a unit of Anthropological studies, like an island in the midst of the sea of the millions of highly heterogeneous urban people.

One example is Tsuyoshi Kato's study of urban ethnicities. He proposes the following three forms in which "urban ethnicity is expressed": (1) networks of family members, relatives, and people of the same local origin; (2) quasi-ethnic associations such as kin-based associations, clan-based associations, and locality-based associations; (3) ethnic associations, such as ethnic dance-and-music groups, ethnic students' unions, ethnic religious organizations, and ethnic political organizations. ${ }^{26}$

A different way of discussing the matter is that there are networks of relatives, localitybased associations, dance-and-music groups, students' unions, religious and political organizations, as well as ethnic associations. The Jakartans keep extending their networks of human relationships along whatever themes and principles are available and suited to their needs, convenience, and tastes. A person extends his/her network basically by being introduced by someone with whom he/she is already acquainted (kenal) to someone who has some reason or potential tie that has resulted in meeting him/her. That may be their common ethnicity, occupation, hobby, educational background, religion, residential proximity, mutual friends, or something else, anything else. Most likely a combination of multiple principles, combined in the way that makes sense only to the person who combines them around his daily activities. A sister's (family) husband's (marriage) brother's (family) friend's (introduced by a mutual friend at a conference) wife (marriage), who happens to be a foreigner, can be easily included in this network, and she can enjoy the comfort/protection of his air-conditioned official white Honda. The outcome is that people are divided into two categories, kenalan (acquaintances) or tidak kenal (not acquainted).

Once formed, however, there are always hierarchical directions to be found among the participants. As the complex streets, which otherwise would appear to be a maze, can be printed as a street-map by being organized along the north-south and east-west axes, so the hierarchical directions, based on any religious or ethnic values (Minangkabau, Java, or whatever at hand), seniority, employment, or sex, regulate behavior/manners among the participants and enable them to formulate a route-map of their relationships. However extensive the individual sequences of ties that relate any two persons, they are translated, in one stroke, into one set of relations, a relationship pattern governing which person is to patronize the other and which person is to accept the favor respectfully.

One outstanding feature of New Order Jakarta is the strong necessity, both emotionalpsychological and socio-economic, to form a network of human relations, which promotes the shapeless ever-extending multiple formations of networks in Jakarta. Here little can be accomplished in any field of social life without the help of personal relationships.

I still remember the basic sentences of the Indonesian textbook for foreigners with which I studied the language.

\footnotetext{
${ }^{25}$ See Saya Shiraishi, "Silakan Masuk, Silakan Duduk [Please come in, please take a seat]: Reflections in a Sitting Room in Java," Indonesia 41 (April 1986): 109-10.

${ }^{26}$ Tsuyoshi Kato, "Urban Ethnicity in Indonesia: Networks and Locality-based Associations," Southeast Asian Studies 23, 4 (March 1986): 391-92.
} 
Wah, panjang sekali ni yg baris beli karcis.

Mana bisa depat karcis begini?

Ia, ya. Saya sih nggak nyangka sepanjang ini orang antre.

My, what a long line to buy tickets.

How can (we) get tickets this way?

Tunggu sebentar, ya?

Yes. I didn't expect the line to be this long.

Saya punya teman didalam.

Wait a second, will you?

I have a contact (lit. friend) inside.

Ya deh. Saya tunggu disini.

Barangkali dia bisa tolong kita.

OK. I'll wait here.

Probably he can help us.

Nah, ini karcisnja sudah dapat.

Ayo kita masuk.

Now, here I've already got the tickets. Let's

Ayolah, kita masuk. Pintar juga, ya, kamu cari karcis. go in.

OK, Let's go in. You sure are smart at getting tickets, aren't you.

Rupanya, banyak teman nih di Jakarta.

You seem to have many friends here in Jakarta.

Abis, di Jakarta kalau nggak banyak teman, susah, dong.

That's the way it is in Jakarta. If you don't have a lot of friends, it is hard.27

It is just like the way one deals with the main streets of Jakarta, which are divided by stout concrete dividers into four lanes-a fast and a slow lane in each direction. To reach one's destination, say an office on a side street, one has to know the location of the openings in these concrete dividers through which a car can enter, first, the slow lane and then the side street. The operation can be highly complex if one has to cross two lanes of opposing traffic (the main street is virtually four one-way streets, divided by the concrete dividers, but put together side by side) before getting into the target street, and then to the office. The official street map does not help in this maneuver. One needs to have a precise, specific, therefore highly personal, knowledge. Here the assistance of someone who knows the way is useful and sometimes essential to reaching one's goal. The government itself has contributed in this sense to the development of the multitudinous personal networks. When the taxi I was taking had to go through this search along the newly reinforced concrete dividers just to make a turn, the driver said, "There are too many aturan [regulations] in Indonesia."

When I wanted to see the school life of children in Jakarta, I was lucky to have a friend whose father had strong connections with some of the private schools.

My friend (I am very thankful to him) asked his mother (his father was away then) to introduce (memper-kenal-kan) me to the teachers of one of the schools. That evening, his younger brother, who lived with the parents, came with his Matsuda car to pick me up

27John U. Wolff, Beginning Indonesian Part Two (Ithaca: Cornell Southeast Asia Program, 1971), pp. 5-6. 
at my lodging. I was already in bed, but there was no way of politely saying no to this kind invitation. The whole plan had already been laid without my being consulted. I was to stay at their father's house that night and go to the school early the next morning to be introduced to the school board chairman. During my research period I would stay in the nearby house of a retired school principal who was a long-time friend of the father.

The fact that the school where I had wanted to do my research was not the school their father chose for me, and that I had already chosen a boarding house, simply did not count. In retrospect, it was I, demanding that my own decisions be respected, who was unreasonable. Because there is no principle in formulating the kenalan networks that says "please introduce me to that person; then leave me alone afterward."

Introducing (menper-kenal-kan) someone to another is a sacred ritual of extending the network of kenal-an (acquaintance) human relations by initiating a new member and, consequently, the new member's own network, into the network of the other's. What I should have known/should have done was to decide either that I would be gratefully included in his courtyard, and accept, like the little grandchild Susi after she learned her lesson, whatever he was prepared to offer me, or else stay outside. There was really no place on the border, somewhere between.

In my friend's father's mind (he was a well-respected socially influential person), therefore, I had asked him to become my patron (bapak, Lit. father) and take me in as a new protégé (anak buah), not just to introduce me casually to some of his friends. Because he would be able to introduce me to the board chairman only if I were one of his anak. If I were to remain a stranger, he could have done nothing for me. Introducing me to someone and accepting me as his anak buah are, therefore, two sides of a single coin. Though I had never met him before, I was generously accepted as eligible to become his protégé because I was his son's friend.

Being a bapaklanak buah is not a half-hearted part-time relationship. One has to submit everthing. In my case, I was to submit all information regarding my official papers and status, purpose of my research (not as a membership qualification, being a friend of his son was enough for that, but as necessary information bapak has to know about his anak buah in order to protect him/her), and my own, however meager, network of human relations, with whom he was to make contact soon. For his part, he thought out and planned whatever he could possibly do for me. As a bapak, he was prepared not only to help me, but also to take responsibility for my entire activities with respect to the board chairman during my stay in Jakarta.

In return, any anak is expected to observe a certain pattern of respectful behavior and responsibilities toward his/her bapak in order to repay his favors and protection. Under these unwritten understandings, I was supposed to wait for him to decide on my research site and lodging, and then accept them, and be grateful for all he provided for me. In the end I was escorted (antar) in their Matsuda to the school to be introduced to the chairman.

The tiger roared, asking help to set him free. I [a mother wolf] would like to help you provided that you promise not to eat me. No. Trust me. I will not eat you. The wolf pitied the tiger and helped him out of the trap. After the tiger was set free from the trap, he desired to eat the wolf. They thus began to quarrel. ... 
... It the end the tiger entered the trap again. It was the tiger who did not know gratitude [balas budi]. ${ }^{28}$

In this personal network, disputes among its members are solved by its own unwritten codes, rather than by official state-operated judicial systems. In other words, no uniformed policeman in his legal status is to be summoned into this domain. Some members of the household gossiped about one of my friend's sisters, saying that she had once taken the household money away by threatening the housemaid with a sharp cooking knife. No one, however, reported the incident to the police. She was the trouble-maker that most networks of human relationships seem to contain among their members, but she was never considered an armed robber. She was even better off than those family members, whose stories we may often encounter in TV dramas and movies in Indonesia, who are regarded by their families as mad-mostly young women considered to be sexually over-active-and are physically constrained inside the house.

In general, if a member of this protective and affectionate human network picks money out of another member's pocket, it is pinjam (borrowing). No thief, no pickpocket can ever manifest himself inside this peaceful cosmos. There may only be an untrustworthy uncle, who is apt to forget (lupa) to return the money he borrowed. Hence all thieves intrude from outside, all pickpockets roam about outside the courtyards, on the streets and in the bus and train (the transportation for many strangers), in search of victims who are exposed to the outside climate.

Robbers and pickpockets belong to this outside world-together with the policemen who pursue them there on the streets. One of the first things a foreign visitor is told by her newly acquainted Jakartan friends is to watch out for the police as much as for the pickpockets on the streets.

Thus, all the robbers, pickpockets, and policemen belong to the streets, much as the sun's "parching" heat belongs there. As we learned through the children's stories with Reni and Susi, this is the reason the air-conditioned courtyards and secure protective networks have to be created and strengthened, amongst the millions of strangers, thousands of policemen, and hundreds of official papers which have to be signed before one can obtain any kind of permit in this city.

At night, when everyone is already asleep, there still are the policemen who patrol. Many robberies and burglaries are committed at night, especially in big cities. They watch over those who roam about the streets. It is possible that they are criminals. ${ }^{29}$

\section{Drove the Toyota Jeep, Alone}

The coup attempt of October 1, 1965, triggered the downfall of Soekarno, and prepared the stage for the New Order regime led by Soeharto. Yet to this day, the person, or the party, who is ultimately responsible for initiating the coup has been disputed, and several possible to probable scenarios have been proposed. ${ }^{30}$ Nonetheless, hundreds of thousands of people

\footnotetext{
${ }^{28}$ Asmana, Serigala dengan harimau [A wolf with a tiger] (Semarang: Mandira, 1988), pp. 4-12.

${ }^{29}$ Macdonald Education Ltd. and Dispen Mabak Republic Indonesia, Polisi [Police], Pustaka Dasar 13 (Jakarta: PT Gramedia, 1981), p.5.

30J. D. Legge, Sukarno: A Political Biography (London: Lane, 1972), p. 391: "Several main categories of interpretation have established themselves. At one extreme was Untung's own explanation of his actions-that he had acted to protect the President from a generals' coup. The PKI, in disarray after 1 October, attempted to brush aside the coup as an internal affair of the army. The army saw it as a simple and straightforward PKI bid for
} 
in the countryside of Indonesia were killed or sent into exile in the aftermath of the abortive coup in Jakarta. Many of them were the members of, or in some way related to, the Indonesian Communist Party (PKI, or Partai Komunis Indonesia), which Soeharto, then Commander of KOSTRAD (Army Strategic Reserve Command), identified pointblank as the mastermind (dalang) behind the coup, but the massacre reached beyond any PKI affiliation. ${ }^{31}$

The affair started with attacks on the houses of the seven top army generals in the early morning of October 1. The accounts of what happened in these houses and how were mostly supplied by the newspapers in the months following the coup. In contrast to the numbers of assorted, varicolored scenarios of the coup that have been proposed, these accounts seem to have been accepted without much controversy. The deformingly detailed descriptive images of the bloody raids were thus left to sink unchecked into the imagination of the readers, and the mass killings which were to follow shortly afterward, largely took after the imagined styles of the raids and murders thus germinated.

The journalist Brian May once commented in his book: "Indonesia was born after a kidnapping; it was to be reborn in a putsch and baptised with the blood of a massacre." $32 \mathrm{He}$ meant, by "a kidnapping," the famous Rengasdengklok Affair of August 16, 1945, in which Soekarno and Hatta, who were to become the First President and Vice President of independent Indonesia, were kidnapped; by "a putsch" the coup attempt of October 1, 1965; and by "a massacre" the mass killings that followed in 1965-1966.

Yet, as Benedict $R$. Anderson and his colleagues pointed out, 33 the Rengasdengklok Affair and the coup attempt of 1965, along with the social revolutions of 1945-1946 which took place in the early phase of Indonesia's independence war, show basic similarities, to which Anderson applied the term "pemuda movement."

For the older word kedaulatan (sovereignty or authority), so often, in this time of revolution, married to rakjat (the people), gave birth to the new word mendaulat, which acquired rapid currency all over Java, and which meant the deposition, humiliation, kidnapping, or murder of hated officials or other representatives of authority, usually carried out by groups of armed pemuda [youth].

Most of the daulat actions mirrored the example set in the Rengasdengklok Affair, in which the pemuda had kidnapped older leaders to compel them to make a political decision they had previously evaded through caution or fear. Though some ended in murder, the great majority did not. ${ }^{34}$

Indeed, as we will soon examine, the principal maneuveur of the 1965 coup was a number of kidnappings of top armed forces officers and governmental officials. Some of these ended in murder, some did not.

The massacre in the aftermath of the coup also took place as hundreds of thousands of kidnappings and murders which were described as follows: "Kidnappings and murders

power and this interpretation, buttressed by the confessions and the trials of those involved, became the received view and the justification for the appalling massacres of communists which swept across Java and Bali in the months that followed."

31 Pipit Rochijat, "Am I PKI or Non-PKI?!" Indonesia 40 (October 1985): 37-56.

32 Brian May, The Indonesian Tragedy (Singapore: Brash, 1978), p. 92.

${ }^{33}$ Benedict R. Anderson and Ruth T. McVey with the assistance of Frederick P. Bunnell, A Preliminary Analysis of the October 1, 1965, Coup in Indonesia (Ithaca: Cornell Modern Indonesia Project, 1971), pp. 24, 26, 30.

${ }^{34}$ Benedict R. O'G. Anderson, Java in a Time of Revolution: Occupation and Resistance, 1944-1946 (Ithaca: Cornell University Press, 1972), pp. 334-35. 
rampaged (Penculikan dan pembunuhan merajalela) $3{ }^{3 \prime \prime}$ The phrase inevitably reminds us of the rhetoric of the Indonesian revolution, "the Revolution runs amuck, rampages, sweeps people along like a tidal wave." 36

What we may perceive in this series of incidents seems to be less the historical stages as indicated by Brian May's words than the repetition of the pemuda movement. Yet the New Order Era which was to follow the mass killings of 1965-1966 has displayed characteristics which contrast sharply with the era after the Revolution. With that in mind, let us examine these historical incidents.

Twenty years after the Rengasdengklok Affair, Soekarno himself vividly described the incident in his characteristically theatrical manner.

A delegation of pemudas awaited me on the verandah. "Now, Bung. Now, tonight [August 15, 1945]," commanded Chairul Saleh. "Let us make a large-scale revolution tonight. we have Peta troops, pemudas, Barisan Pelopor men, even the Hei Ho auxiliary soldiers are all prepared. At your signal Jakarta will be in flames. Thousands and thousands of armed and ready troops will surround the city and carry out a successful armed revolt and topple the whole Japanese army." ${ }^{\prime 37}$

Soekarno's own anak buah (protégés) were trying to force him to move by seizing the opportunity of Japan's surrender to the Allies on August 15, 1945.

He [Wikana] tried to bluff me. "We don't want to threaten you, Bung," he rasped, taking a menacing step toward me, an outstretched knife in his hand. "But the Revolution is now in our hands and we COMMAND you. If you do not make the Revolution tonight, then...."

"Then what?" I cried, leaping out of my chair in blazing fury,. "Don't you threaten me. Don't you dare command me. You will do what I want. I will never be forced into YOUR will!" 38

This was in fact the very moment of the revolution, Indonesian style. An anak buah, the minor member of the network of human relations whose behavior is regulated by the hierarchical bapak-anak buah order, is to accept, like the little grandchild Susi, whatever is offered him by his loving protector, bapak. Now, however, the anak buah is COMMANDing (The emphases in the quotation were in the original) his bapak to make the "Revolution"!

Soekarno managed once to make the feverish pemuda leave his house, but a few hours later, very early in the morning (about 3:00 a.m.) of August 16, they came back again. This time with another revolutionary strategy. To reverse the route-map of bapak-anak buah relationships. To reverse the direction of the flow of command/respect behavior. Instead of the anak buah, as is usually the case, paying a respectful visit to their bapak's house, the bapak was to make a visit to his anak buah's place. In short, the anak buah are going to kidnap their bapak.

\footnotetext{
${ }^{35}$ Soegiarso Soerojo, Siapa Menabur Angin akan Menuai Badai: G30S-PKI dan Peran Bung Karno [Whoever spreads winds is to reap the storm: G30S-PKI and Bung Karno's Role] (Jakarta: Soegiarso Soerojo, 1988), p. 232.

${ }^{36}$ Benedict R. Anderson, "Reading Revenge' by Pramoedya Ananta Toer (1978-1982)," in Writing on the Tongue, ed. A. L. Becker, Michigan Papers on South and Southeast Asia 33 (Ann Arbor: Center for South and Southeast Asian Studies, The University of Michigan, 1989), p. 70.

${ }^{37}$ Cindy Adams, Sukarno: An Autobiography as Told to Cindy Adams (Second Printing; Hong Kong: Gunung Agung, 1966), p. 206.

${ }^{38}$ Ibid., p. 208.
} 
I heard sounds from the bushes, and a band of uniformed pemudas walked in stealthily.

Sukarni had a long-handled knife as well as a pistol. With the true flair of an adventurer, he pulled his knife and barked, "Get dressed. ... The time has come." ...

... "It has been decided to remove you to safety."39

Soekarno, an extremely experienced politician for whom politics had been the only vocation to which his entire life had been dedicated, made up his mind to yield to the pemuda this time.

I put my uniform on. I looked ridiculous. It was too small, but there was little point in explaining their plan was not well thought out. They acted and thought as swashbuckling adventurers. I guess if they had ever stopped to think what was really happening they'd have died from fright and wouldn't have been able to fight for their country at all. Anyway, I buttoned the uniform on over my pajamas. ${ }^{40}$

Thus about 4:00 a.m., Soekarno, his family, and Hatta left their houses in Jakarta for Rengasdengklok in two cars escorted by young uniformed pemuda.

Yes, the pemuda needed two cars to carry out their revolutionary kidnapping mission. They, the kidnappers, were the pioneer-fathers of the busy contemporary pen-jemput (person who comes to pick up someone) and peng-antar (person who escorts someone someplace), whose cars jam the streets of Jakarta. Back in 1988, on our way home after watching a play, Eko's mother was rightly alarmed when she sensed the possibility of the route-map being reversed. A small Rengasdengklok Affair was about to take place. And it was not even for patriotism, but because of, in her opinion, her young daughters-in-laws' habits of smoking.

Though I have not discovered how the pemuda managed to lay their hands on the two cars, the following passage indicates the conditions these young forefathers had to meet to have access to cars in 1945 . The quotation will also suggest the strikingly different tone Soekarno employed concerning the act of stealing in contrast to that of Soeharto in the New Order.

On August 18, two days after Rengasdengklok Affair and the day after the Proclamation of Indonesian Independence, Soekarno was chosen to become the First President.

My devoted follower decided a "Presiden [President]" had to have a limousine so they "arranged" for one. Sudiro knew of a seven-passenger Buick which is "the biggest, most beautiful in Jakarta and has curtains in the back window." Unfortunately this Presidential limousine happened to belong to the Japanese Chief of Railways. Such a minor detail did not trouble Sudiro. Unknown to me he went hunting for the car and found it parked in a garage.

It happens that Sudiro knew the driver and said to him, "Look, I want you to give me the keys to the car."

"Why?" asked the boy, terrified.

"What do you mean, 'Why?'," repeated Sudiro, shocked by such stupidity. "Because it is my intention to steal it for our President."

"Oh, okay," grinned the patriot, climbing happily out of the front seat and handing the keys over.

${ }^{39}$ Ibid., pp. 210-11.

40 Ibid., p. 212. 
"Quick," ordered Sudiro, "head back for your village in Central Java before anyone knows what happened and hide yourself well because it will be dangerous for you to be around here once this is discovered."

Sudiro had the keys and a beautiful, big, black seven-passenger limousine with curtains in the rear window-but he couldn't drive. Few of us could. Where should we learn? Natives had no cars during Dutch time and only officials were permitted them in Japanese time. ${ }^{41}$

Thus Indonesia was born after the free use of cars had become somewhat possible for her people, enabling the political kidnappings to be carried out. After all, stealing a car and kidnapping (stealing a human being) are nearly identical activities. And the stealing of a car, in the above context, signified rejection of the imagined right of the Japanese to own the car, and the kidnapping of the bapak signified rejection of the imagined right of bapak to summon his anak buah. If in ordinary times a bapak is the center of a small cosmos, under whose eaves all other minors come to receive his favors and protection, he is, in the revolutionary context, made to become a mere satellite and is brought to a satellite station in outer space.

According to Soekarno's own assessment, the kidnapping, or the revolutionary reverse of the route-map of human relations, was intended not only for Soekarno's safety from the expected uprising in Jakarta and from arrest by the Japanese Occupation Army, but also for persuading him to join their cause by isolating him from his ordinary surroundings and showing him their sincerity and determination, as well as preventing him from interfering in what they planned to carry out, a revolution.

Meanwhile, in Jakarta in the absence of Soekarno and Hatta:

An emotional argument ensued in which Nishijima tried to persuade Wikana to reveal the location of the two leaders, promising that if Wikana did so Nishijima and Maeda [Rear-Admiral] would cooperate fully in having Indonesian independence declared. ${ }^{42}$

Soekarno and Hatta were back to Jakarta late that night, and the declaration of independence was hastily drawn up in Maeda's house, and Indonesian Independence was proclaimed the next morning at 10:00 a.m., August 17, 1945.

Now we are back to the attempted coup of the morning of October 1, 1965. For most of the people, the incident began with the initial statement of Lieutenant Colonel Untung, a leader of the coup group, which was broadcast over RRI (Radio Republik Indonesia) at around 7:15 a.m.

On Thursday, September 30,1965, a military move took place within the Army in the capital city of Djakarta which was aided by troops from other branches of the Armed Forces. The September 30th Movement, which is led by Lieutenant Colonel Untung, Commandant of a Battalion of the Tjakrabirawa, the personal bodyguard of President

Sukarno, is directed against Generals who were members of the self-styled Council of Generals. ${ }^{43}$

The best account of the Cakrabirawa, the personal bodyguard of President, may be found in Soekarno's own biography.

\footnotetext{
${ }^{41} \mathrm{Ibid} .$, Pp. 222-23.

${ }^{42}$ Anderson, Java in a Time of Revolution, p. 76.

43"Selected Documents Relating to the September 30th Movement and Its Epilogue (Compiled by the Editors)," Indonesia 1 (April 1966): 134.
} 
On my birthday in 1962, Tjakrabirawa was instituted. A special unit of 3,000, drawn from the four armed forces, Tjakrabirawa's job is to safeguard the President. Each man is an accomplished paratrooper. Each was an outstanding guerrilla fighter. Three hundred of my bloodtype act as bodyguards. Another detachment of specialists regulates my likes and dislikes. They know I enjoy entertainment so one special corps sings, dances, and doubles as musicians at every party. They know my habit of touching microphones before I speak so the regiment's electronic detail brings its own equipment. They know my favorite foods so at any outside buffet Tjakrabirawa technicians pretest each dish before it leaves the kitchen....

I used to be able to slip out of the palace alone on occasion. Since Tjakrabirawa I no longer can. The morning after the last time I tried a very polite but firm note was delivered to me. It read: "Dear Bapak. We are responsible for you. Please do not try to sneak away again. (Signed) Your Guards."44

We can sense from Soekarno's own words that his personal bodyguard made up of proud elite members of the armed forces thus had a close personal relationship with their Bapak, rather than President, as they called him.

The broadcast continues:

A number of Generals have been arrested and important communications media and other vital installations have been placed under the control of the September 30th Movement, while President Sukarno is safe under its protection. Also a number of other prominent leaders in society, who had become targets of the action by the Council of Generals, are under the protection of the September 30th Movement. ${ }^{45}$

Thus, according to the broadcast, there were two operations pursued by the coup group, besides gaining control of the communications media. These were arresting the generals and protecting President Soekarno and "other prominent leaders in society."

We will start by examining the arrest of the generals. At about 4:00 a.m., the prime time for political kidnappings since August, 1945, three hours before the radio broadcast, seven squads wearing Cakrabirawa uniforms arrived in their trucks at the houses of the generals. (Besides the weapons used, the vehicles, trucks, buses, and jeeps, belonged to the Air Force as well as to Cakrabirawa. ${ }^{46}$ This may mean something, or may not in Indonesia). Had Lieutenant Colonel Untung been at the house of General Soeprapto, Second Deputy to the Minister/Commander of the Army, to witness his men carrying out the raid, he would have been quite satisfied.

There it split into three, the first two groups guarding the side entrances and the garage, while the third entered the house, under the direct command of Sulaiman. Unable to sleep because his molars had been removed quite recently and disturbed by the barking of his dogs, Soeprapto went to the front door in his T-shirt, sarong and sandals. Corporal (Second Class) Suparman answered his queries, by giving him a military salute and reporting that the President wanted to see him immediately. Without allowing the unfortunate General either to put on his clothes or even shut his own front door, he was hustled into the waiting truck. Mrs. Soeprapto, who had watched the scene through the

\footnotetext{
${ }^{44}$ Adams, Sukarno, pp. 309-10.

45 "Selected Documents," Indonesia 1, p. 134.

46Harold Crouch, The Army and Politics in Indonesia (Ithaca: Cornell University Press, 1978), p. 118; Soegiarso Soerojo, Siapa Menabur Angin, pp. 201-3.
} 
window, was upset and astonished, finally coming to the conclusion that her husband was being put under arrest. [Emphasis added.] ${ }^{47}$

According to the broadcast statement, the operation was meant to be the "arrests" of the generals, and indeed General Soeprapto appeared to be arrested, under the authority, probably, of the President.

The raid on the house of General Parman, First Assistant (Intelligence) to the Minister/Commander of the Army, presents an example which illustrates the nature of the operation.

It was about 4:00 a.m. when a group of some twenty soldiers appeared outside Parman's house in Djl. Serang. Hearing a noise outside, the general, (who with his wife was practicing melekan [the practice of staying up all night in prayer, meditation, or ascesis to draw on the power of the supernatural world]), went out into the garden. He apparently thought that a robbery was being carried on at the house of his next door neighbour. Observing a group of Tjakrabirawa inside his own front courtyard, he asked them what they were doing. They answered that they had been ordered by the President to pick him up. Apparently suspecting nothing, or giving no sign of it, Parman went back into the house to change, and the main part of the raiding group followed him in. In spite of his wife's anger at what she felt to be Tjakrabirawa rudeness, Parman quietly changed into his uniform, and whispered to his wife to contact Yani [Minister/ Commander of the Armyl immediately. He clearly thought that he was being arrested at Soekarno's orders. But as they left the Tjakrabirawa soldiers picked up the telephone and took it with them. Though Parman himself seems to have suspected what was up, he put up no resistance and was driven rapidly away to Lubang Buaja. It was not until Mrs. Harjono came weeping to Mrs. Parman fifteen minutes after the attackers had left, sobbing that her husband had been shot dead, that Mrs. Parman began to realize what had really happened. For although she was annoyed by the behaviour of the Tjakrabirawa troops, it was the President's habit to summon the Chief of Army Intelligence at unusual hours, and till that moment she had believed that as on many previous occasions he had been summoned for a secret conference at the Palace. ${ }^{48}$

The Chief of Army Intelligence was the only general among the seven victims who left his house in his uniform, leaving behind him his wife who believed that her husband was really "summoned" by the President and was being escorted to the Palace by the Presidential Guard. The squad's visit could have appeared to be an ordinary practice of jemput-antar, in which the Presidential Guard came to escort a high army officer to the Palace. After all, the core of the visitors were members of the Palace Guard, and their targets were top army generals who doubtlessly had kept frequent and close contacts with the Presidential Palace.

As the above description shows, according to the manners and modes of operation, and also the views of the persons who interpret the acts, the simple and seemingly identical maneuveurs of coming to pick up someone (in this case the seven generals) in order to take them some place (Lubang Buaya) can be interpreted differently, either as a Presidential "arrest," or as a Presidential "summons" for a secret conference, forced or voluntary.

In this context, perhaps, General Parman's case could have disrupted the theme of the brutal raid. It was necessary for this reason that the newspapers, or the army information

\footnotetext{
${ }^{47}$ Anderson and McVey, Preliminary Analysis, p. 13.

${ }^{48}$ Ibid., pp. 13-14.
} 
service who provided the information, had to make sure to insert the small piece of information that the telephone was picked up and taken away, in short, stolen. After all it is only the reputation of Mrs. Parman, who seemed to have been undisturbed by this robbery committed in front of her eyes as well as by the kidnapping of her husband, that is to suffer.

The message is clear. The visitors acted not as those who were acquaintances of the generals or of their household members. Unlike the Rengasdengklok Affair, in which the kidnappers were anak buah of Soekarno, the kidnappers of the 1965 coup were treated as a group of strangers with deceptive uniforms, who forcibly crashed into the houses. They were outsiders, and identical, therefore, with the pickpockets who belonged to the streets.

Six out of the seven houses which were raided were located in Menteng, originally created as an exclusively European residential area in the early twentieth century during Dutch Colonial rule. ${ }^{49}$ It still is one of the best residential areas in Jakarta, with uniformly large spacious houses under the deep eaves of rosy-red tiled roofs and stately trees. Reading the accounts of what happened there on that fatal morning, it is rather surprising to learn how easily the raiding parties were allowed to enter the generals' courtyards. We must perhaps note that the thick and high imposing walls that surround most houses in Menteng are one of the phenomena we can observe in New Order Jakarta. Yes, the walls tell us passersby that, if we fortify our houses and courtyards with high fences, we will be able to protect ourselves from these armed invaders who belong outside our households, outside the protective networks of related people, outside the air-conditioned enclaves.

Accordingly, among the seven raids, the style adopted by the team led by SergeantMajor Surono in their assignment at the house of General Soetojo, Auditor-General and Law Inspector of the Army, appears to be an authentic "kidnapping" mission which was carried out with a professional efficiency.

The group opened their assault by sealing off Djl. Sumenep where their victim lived. Next the civil defence guards on the street were disarmed one by one. Then, as in the case of the other Generals, the group divided into three squads, one each at the front and back of the house, the third charged with carrying out the kidnapping itself. They persuaded Soetojo to open his bedroom door on the excuse of bringing a letter from the President, then seized and overpowered him. He was blindfolded, with his hands tied behind his back, and pushed into an awaiting truck, which then drove rapidly back to Lubang Buaja.50

There is no doubt in the above description that General Soetojo was forcefully kidnapped by a group of determined attackers, who did not take for granted the neighborhood civil defense guards' respect for the uniform of Presidential Guard. They relied primarily on their own force, rather than on the authority of the President.

In the case of General Nasution, Coordinating Defense Minister/Chief of Staff of the Armed Forces, his adjutant was mistaken for him and bundled into a truck. General Yani, Minister/Commander of the Army, told the Cakrabirawa that he intended to take a bath before changing from his pajamas into uniform, which enraged the young raiders, who then shot him through the glass door he had closed behind him. (Note that Soekarno in Rengasdengklok Affair wore an ill-fitting small-sized uniform over his pajamas, knowing the danger of contradicting the agitated pemuda, who, perhaps for the first time ever, were try-

\footnotetext{
${ }^{49}$ Susan Abeyasekere, Jakarta: A History (Singapore: Oxford University Press, 1987), see especially plate 19, the photograph of "A street in the new European suburb of Menteng."

${ }^{50}$ Anderson and McVey, Preliminary Analysis, p. 14.
} 
ing to COMMAND their seniors.) Two other generals were also killed in their houses, and then their corpses were carried off in the trucks to the Crocodile Hole.

It was ultimately as "kidnapping [penculikan] and killing [pembunuhan]" rather than the authorized lawful "arrest [tangkap]" or Presidential "summons," that the Army led by then Major General Soeharto chose to characterize Lieutenent Colonel Untung's early morning maneuveur.

The first Army broadcast, which the Army put on the air at 8:45 p.m. October 1, after recovering control of the Jakarta radio station, made the following announcement.

Announcement No. 027/1965 of the Army Information Center.

1. On October 1, 1965, an incident occurred which was carried out by a counter-revolutionary movement, which called itself the "September 30th Movement," in Djakarta.

2. They kidnapped a number of high officers, namely: 1. Lieutenant General A. Yani. 2. Major General Suprapto. 3. Major General S. Parman. 4. Major General Harjono M.T. 5. Brigadier General D.I. Pandjaitan. 6. Brigadier General Sutojo Siswomihardjo.

3. They were able by force to gain the use of the Djakarta Studio of RRI [Radio Republik Indonesia] and the Djakarta Central Telecommunications Office. ${ }^{51}$ [Emphases added]

So the whole operation was stated to have been carried out by force without any supportive authority, transforming all the "arrests" and Presidential "summons" into "kidnappings" and making all the participants in the operation identical with criminals. It was not the police who came into the house to arrest a member of the household. It was armed robbers and kidnappers.

To establish this statement as legitimate, the Army also needed to embrace President Soekarno, who was then the only source of authority. His voice was as yet unavailable, but all his official titles were made use of, indicating that not only his body but the whole official establishment was safe and well.

4. His Excellency, President/Supreme Commander of the Armed Forces/Great Leader of the Revolution Bung Karno, and his Honorable Minister Coordinator for Defense and

Security/Chief of Staff of the Armed Forces, General A. H. Nasution, were able to be brought to safety and are in a safe and well condition. ${ }^{52}$

Here is the basis for discussing whether, if President Soekarno had made a supportive broadcast identifying the early morning operation as a series of "arrests of counter-revolutionary generals," instead of waiting for Major-General Soeharto to characterize it as a series of "kidnappings of revolutionary heroes," his voice could have effectively decided and changed the course of the coup, hence the course of history.

In other words, the above discussion implies that, as a matter of fact, arresting someone and kidnapping someone are physically identical. Both acts eventually take someone from somewhere to somewhere else. It is, therefore, a matter of strategic interpretation whether the acts were carried out by legitimate authority or by force itself. We may also bear in mind here that both kidnapping (penculikan) and arrest (penangkapan) thus belong to the same family of jemput-antar. They constitute identical conduct with different names. Because of

51 "Selected Documents," Indonesia 1, p.158.

${ }^{52}$ Ibid. 
this fact, the operation demands that a specific name be given which will eventually change the course of history.

Indeed the main reason for the abortive coup having been subject to a wide range of conflicting interpretations ${ }^{53}$ seems to have arisen out of the multiple possible interpretations of the movements of crucial figures such as President Soekarno, PKI Chairman Aidit, Air Force Commander Omar Dhani, and members of PKI-affiliated Gerwani (Women's movement) and Pemuda Rakyat (People's Youths) on the fateful day of October 1. All of them were found to be at Halim Air Base, which served as the base of the coup attempt, and Lubang Buaya (Crocodile Hole), where the generals were brought and killed, was a part of its training field. Were they there because they were the leaders of the coup? Or were they kidnapped and brought to Halim by the coup group in a manner similar to the Rengasdengklok Affair?

Let us proceed, at this point, to examine the second maneuver of Lieut.Col. Untung: the protection of President Soekarno and other prominent leaders in society.

The presence of Aidit, Coordinating Minister of Soekarno's Dwikora Cabinet as well as Chairman of the PKI's Central Committee, at Halim on October 1 has been rather vaguely mentioned. In his biography of Soekarno, J. D. Legge gave a list of questions concerning the PKI's involvement in the coup attempt in connection with Aidit's presence at Halim.

All interpretations have their inconsistencies to be explained away. If the PKI was as innocent as it claimed how did Aidit happen to be at Halim on the morning of 1 October? On the other hand, if the coup was a PKI plot how was the absence of key PKI leaders-Njoto who was in Medan with Subandrio's party, Lukman and Sakirman who were in Semarang - to be explained? Why were they not standing by to assist in the direction of events? Why were not plans made for a mass insurrection to support the coup if necessary? Why was there no prior deployment of communist forces to seize power outside the capital? How does one explain the extraordinary clumsiness by which Harian Rakjat, the PKI daily, came out in support of the coup on 2 October, after it had been effectively crushed? Why did the PKI subsequently take no steps in its own defence, but passively await its fate? Had it, perhaps, as some observers argued, become implicated in a plot which was not of its own making?54

Note that among the eight questions which Legge raised, there is only one which directly conflicts with the PKI's claim of innocence. That is: "How did Aidit happen to be at Halim on the morning of 1 October?"

Aidit's letter to Soekarno dated October 6 explained his moves in the following manner (I have no means at this point of knowing whether the letter is authentic or not):

1. On September 30 th, at midnight, I was taken by people wearing Cakrabirawa uniforms (whom I did not know [tidak saya kenal]) with the following explanation: [I was] summoned to the Palace for an emergency cabinet meeting. However, the vehicle proceeded toward Jatinegara. Later, [we] changed cars and then went to a kampung where [I was] placed in a small house. There I was informed that arrests were going to take place of members of the Council of Generals. On October 1, I was informed that the operation aimed at the Council of Generals had already been successful. I asked "Has this been

${ }^{53}$ Crouch, The Army and Politics, pp. 101-34.

${ }^{54}$ Legge, Sukarno, pp. 391-92. 
reported to PYM [His Excellency]?" And [they] answered that it had and he [beliau] had given his blessing. ${ }^{55}$

There are, of course, different versions of Aidit's movements that day. If he were the mastermind of the coup, he surely should have known at least whence he was to be escorted on that crucial night?

Before that [operation] at 22:00 on September 30, Air Force Major Suyono had the duty of men-jemput [picking up] D. N. Aidit, Chairman of CC PKI, who had waited in the house of Sjam, in Jalan Pemuda. According to the confession of Suyono before the sidang Mahmilub [Special Court-Martial] he arrived by Toyota jeep. D. N. Aidit was already prepared to leave for Halim with Major-General Pranoto. ${ }^{56}$

On the other hand, Mrs. Aidit

is reported to have told Army authorities that her husband had been kidnapped by rightist elements and taken to an unknown destination. (See $A F P$ report from Singapore, October 7.) Another source claims also that Aidit was "kidnapped" (dilarikan). Significantly this is from an anti-Communist Islamic paper which would not be likely to put Aidit in a favorable light. (See Duta Revolusi, October 9.)57

Thus Aidit's moves during the critical moments, and therefore the PKI's commitments in the coup, still remain open to different interpretations of the single fact of his being escorted to Halim.

Another fact which has been pointed out as proof of PKI involvement is the presence of members of PKI-affiliated associations, Gerwani and Pemuda Rakyat, at Lubang Buaya, and their participation in the killings of the generals. Ben Anderson and his colleagues provided a revealing analysis of this matter:

Almost all of the "confessees" were people who had been receiving miliary training at Lubang Buaja on a regular basis for the past two months, and who indeed had been at the base at least since September 28 carrying out their normal exercises. The routine had evidently been established that they would be picked up from their homes in trucks, lodged in tents at Lubang Buaja for the duration of the training period, and then taken home again in the same way. ${ }^{58}$

Thus by establishing a routine of such a simple operation as sending vehicles to pick up the necessary personnel, "the conspirators cut successfully into the line of hierarchy [of PKI] and effectively assumed control of these lower cadres without anyone being the wiser." 59

By now we may well assume that picking up someone is a national obsession of Indonesia since the days of its birth, and we might think twice before gratefully being picked up at the airport reflecting on the wide range of possible interpretations of that kindly act.

The movements of President Soekarno on the critical day in 1965 have been treated with the utmost care. The more details are "revealed," however, the more contradictions and unanswerable questions seem to surface. He left his third wife Dewi's house at about 6:30

\footnotetext{
${ }^{55}$ Soegiarso Soerojo, Siapa Menabur Angin, pp.232-33.

56Ibid., pp. 217-18.

${ }^{57}$ Anderson and McVey, Preliminary Analysis, p. 69.

58Ibid., p. 21.

${ }^{59}$ lbid., p.23.
} 
a.m., and arrived at Halim, rather than at his official residence Freedom Palace, almost three hours later, at 9:30 a.m. From there, he left for his Palace in Bogor 12 hours later. At the time of Lieut. Col. Untung's first radio broadcast, Soekarno was still in his car traveling around the streets of Jakarta.

The following account is found in a recently published controversial book whose author is said to have had special access to Army intelligence information, and therefore is believed to side against the PKI and Soekarno.

The task of inviting [memper-silakan] President Soekarno to set out to Halim that night was not successful either, because the President apparently was not to be found in his Palace. After giving a speech for Munas Teknik in Senayan, the Friday night of September 29 [sic], 1965, Bung Karno went to pick up [men-jemput] Dewi at Hotel Indonesia. And he stayed in the house of Ratna Sari Dewi. ...

Brigadier General Suparjo was in the Palace from 6:00 in the morning [October 1]. His task was to meet [men-jemput] President Soekarno [at the Palace] and escort him to Halim. ${ }^{60}$ Base.

Soekarno himself afterward made repeated statements about his journey to the Air Force

6. President Soekarno's First Press Interview after the collapse of the September 30th Movement. Given and Published on October 14.

[The translation is based on an Antara report carried in the Protestant newspaper Sinar Harapan, October 14, 1965.]

... He explained that when, at his own desire and not because of pressure or threats from anyone, he left, Freedom Palace on the morning of October 1 to go to Halim Perdana Kusumah Air Base, those responsible for escorting and guarding him were units of the Tjakrabirawa, who carried out their duty most effectively. "So too when I left Halim for Bogor, those who escorted me-'escorted' in the good sense of the word [mengawal in de goede betekenis van het woord]-were the Tjakrabirawa. Also at this point I wish to stress once again that my departure to Bogor was at my own desire [atas kehendak saja sendiri] and not because of any pressure or threats." 61

The reason he had to make such an emphatic, or even apologetic, statement regarding his own movements was because he had been escorted by his guards, Cakrabirawa, all the time, and from this perspective there was no difference between whether he had been forced to go to Halim by them, or someone behind them, or whether he had gone there on his own initiative, in which case he would be questioned further about his involvement in the abortive coup.

Twenty-four years after the coup and twenty years after the death of Soekarno, those who had escorted him to Halim on the morning of October 1 would talk about their journey in the following New Order language:

This alternative was not adopted, because Colonel Saelan [Deputy Commander of Cakrabirawa Regiment] gave the instruction to take [mem-bawa] the President to Pangkalan AURI in Halim. Mangil [Adjunct High Police Commissioner, and Commandant of the Personal Bodyguard Detachment] could accept it because it accorded with

${ }^{60}$ Soegiarso Soerojo, Siapa Menabur Angin, p. 218.

61 "Selected Documents," Indonesia 1, pp.154-55. 
the existing guideline, which stated that, in case the President was in danger, he could be driven [di-lari-kan] to the nearest ABRI barracks, Halim Perdanakusuma Air Base (there is a presidential airplane, Jetstar, which is always ready to take off), Tanjungpriok (there is the Navy boat Varuna awaiting) or the Bogor Palace (there is the helicopter). ${ }^{62}$

In September 1989 when a weekly magazine was trying to trace Soekarno's footsteps, the most sensational news in Jakarta was the murder of a 21-year old woman whose corpse had been discovered without head or hands.

On Wednesday morning, August 30, apparently, Buti [fiancé of the victim, who was the first suspect but said to have been proved innocent] only brought [meng-antar] Titin [name of the headless victim] to a place in accordance with her wishes. From there Titin was taken [di-bawa] by her secret lover to a motel, until the evening. ${ }^{63}$

Note the difference in the tone of the two words, antar and bawa, through which the two identical actions of taking someone somewhere are differentiated. They discriminate between the action of her loving legal fiancé taking her to a place in his car in accordance with her wish, and her loving but illegal lover and would-be-murderer taking her to another place without her wish being identified. Titin may actually have gone to the motel voluntarily, or even willingly, thinking that she was being escorted (antar) by her secret lover. But the writer of the article was now imagining a murderer prevailing over his victim, and hence chose the word bawa (bring, carry).

The fact that the same word bawa is now used for Soekarno by his bodyguards seems to be significant enough. Had the old President, who was then 64, and had health problems, already become a caged bird to his escorting bodyguards who now claim to have decided where to take (bawa) the President? Or, twenty years after his death, has the flamboyant President, who, some people still believe, could have changed the nature of the coup and, therefore, the history of Indonesia, become, along with his once-so-glorified authority, as dead as the headless corpse of the 21-year old woman in the minds of his former bodyguards?

Of course, the claim itself may well be intended to distance Soekarno from the coup group. In that case the fact that the very words of those who are trying to protect Soekarno from accusations regarding his involvement in the coup make him subordinate to the decision of others, clearly shows Soekarno's loss of leadership over the event.

The article on the headless woman, Titin, continues.

And according to the latest news, the following Sunday night around 23:00 the man [the suspect who is supposed to be her secret lover] was driven [di-lari-kan] to the Indonesian Police Hospital in Kramatjati. The suspect, it is said, tried to kill himself by cutting the artery in his hand. 64

\footnotetext{
${ }^{62}$ A. Luqman, "Bung Karno di Saat Kudeta Komunis yang Gagal: Duapuluh empat tahun sudah kudeta berdarah PKI terjadi. Masih saja ada pertanyaaan: Terlibatkah Bung Karno? [Bung Karno at the time of the Communist's abortive coup: 24 years after the bloody PKI coup, there still is a question: Was Bung Karno involved in it?]," Editor 4 (September 30, 1989), p. 15.

${ }^{63}$ Toriq Hadad, Moebanoe Moera, Agung Firmansyah, and Muchsin Lubis, "Asmara-Asmara di Balik Kematian Christine [Romantic involvements behind the death of Christine]," Tempo 30 (September 23, 1989), p. 84.

${ }^{64}$ Ibid.
} 
Both Soekarno and Aidit, who was also an outstanding leader of the late Soekarno era, were thus reported to have been driven (di-lari-kan) by someone other than themselves to Halim, and consequently to their fatal destinations.

In the midst of all this multitude of obsessive activities of picking up someone and/or being picked up by someone, however, there was one man who drove his vehicle to his own destination, or office, all by himself.

I drove the Toyota Jeep, alone, without anyone giving me a command, without anyone guarding me, toward the Kostrad, passing through Jalan Kebon Sirih and Jalan Merdeka Timur. ${ }^{65}$

KOSTRAD (Army Strategic Reserve Command) Commander, Major-General Soeharto, left his house at six in the morning of October 1, after receiving reports of unknown military maneuvers. His was the "departure without escort." The person capable of ignoring the national tradition of jemput-antar, was also capable of recognizing the possibilities of its varied interpretations and implications:

As for the Generals who had been summoned [by President Soekarno at Halim], I forbade them to go, since, quite frankly, in my estimation Halim was the centre of the "Movement" and I did not want to lose any more Generals. 66

His next task was to remove Soekarno from Halim before he sent out troops to attack the base of the coup.

I then repeated it: The task you must now carry out as adjutant is to move (pindahkan) Bapak [the President] from Halim. I will be very thankful to God if you can manage to move (dapat memindahkan) Bapak from Halim. Evidently the adjutant understood what I meant (mengetahui maksud saya), and later did his utmost, since about 10:00 p.m. I got a long distance call from Bogor that the President had already arrived there. ${ }^{67}$

The image of the posture Soeharto then assumed apparently remained impressive in the minds of Indonesians. Not only is the phrase describing him driving his vehicle alone quoted repeatedly, but twenty-three years later his behavior was still praised in the following manner in the same journal that later carried the articles quoted above concerning the headless corpse of a woman.

That morning numbers of generals were reported to have been arrested or murdered. By the afternoon, there was no one who knew precisely what had happened to the Head of the State. In this confusion appeared one senior officer named Soeharto, who took a step forward. He succeeded. Since then, Indonesia has come to know one new leader of its own.68

\footnotetext{
${ }^{65}$ Soeharto: Pikiran, Ucapan, dan Tindakan Saya, p.119. Also, "Selected Documents," Indonesia 1, p.162, "Since it was still very early, and so my chauffeur had not yet arrived, I was forced to drive myself in a Jeep to Headquarters, KOSTRAD headquarters, where indeed I was stationed as KOSTRAD Commander."

66"Selected Documents," Indonesia 1, p. 171.

${ }^{67}$ Ibid.

${ }^{68}$ Goenawan Mohamad, "Pemimpin," Tempo, March 5, 1988, p. 29.
} 


\section{He Was Taken to Safety by His Own Men}

By the evening of October 1, the coup was aborted. There were no Nishijima-Maeda, who stood outside the direct confrontation between the kidnappers and kidnapped and yet were both powerful and sympathetic enough to help them achieve their goals even in a compromising way. clause.

The First Army broadcast on the evening of October 1 concluded with the following

5. The Leadership of the Army is temporarily held by Major General Soeharto, Commander of KOSTRAD.

6. The general situation is again under control and security measures are being actively carried out. The general public is urged to remain calm and continue their respective tasks as usual. 69

The new era was to begin. And the whole incident had to be identified with a new voice for the sake of the new era to be born.

The presence of Air Vice Marshal Omar Dhani, Minister/Commander of the Air Force, in Halim is explained by Major-General Soeharto in his speech of October 15, 1965, which was the first detailed official explanation and clarification of the event. He started the speech by apologizing for not being a competent speaker.

Before I start I would like to ask your forgiveness, my brothers, for any lack of polish and coherence in my analysis, and also for any imperfections in my language-I am no expert at public speaking. ... I am someone who very rarely makes public statements, so that now that I am making a speech, especially to you, my brothers from the Central and Regional National Front leadership, this will more or less influence the rather disorganized form of what I have to say. So I ask your pardon in advance for any such deficiencies. ${ }^{70}$

It was this new voice that thus identified and established the degree and character of Omar Dhani's involvement in the affair.

Secondly I got information that Air Marshal Umar Dhani (sic), who according to the first reports had been kidnapped, had actually been taken to safety (diselamatkan) by his own men (anak buah) at about 3:00 a.m., i.e. about one hour before the affair broke out - since the affair occurred roughly between 4:00 and 4:30 a.m. ${ }^{71}$

The use of the passive voice di-selamat-kan (been taken to safety) spared the Commander of the Air Force from being accused of actively initiating the coup. The fact that it was the air force base that was used as the base of the coup operations; it was air force trucks and weapons that were used in the operation; it was air force personnel who trained the PKIaffiliated teen-aged boys and girls in the base and led them to participate in the killings of the generals who were still alive when they arrived at Lubang Buaya, is considerably downplayed by this single passive verb.

\footnotetext{
69 "Selected Documents," Indonesia 1, p. 158.

70 Ibid., p. 160.

${ }^{71}$ Ibid., p. 164.
} 
The new voice further declared that Omar Dhani, "who according to the first reports had been kidnapped, had actually been taken to safety by his own men" It was, therefore, not a kidnapping. In the Rengasdengklok Affair, Soekarno was kidnapped by his own anak buah. But in the New Order language that is about to be born here, Omar Dhani was not kidnapped but brought to safety because it was his own men who took him to Halim.

At this point, before we are fully immensed from head to foot in the New Order language, let me formulate one aspect of the coup in which anak buah were still capable of kidnapping bapak as a means of a Copernican turn of the world of hierarchical relationships.

Soekarno had never punished these hot-blooded revolutionary-kidnappers-anak buah of the Rengasdengklok Affair, who were in fact to become high governmental officials by the time of the coup of 1965. And again Soekarno was never to blame his anak buah bodyguards, Cakrabirawa, for the abortive coup. He is reported to have said that "That sort of thing is usual in a revolution [Kejadian seperti ini, kejadian biasa dalam revolusi]."72

Indeed he must have been referring to his own experience of the Rengasdengklok Affair, and expressing his understanding of the revolutionary character of the two historical incidents. Let us read further on Lieut. Col. Untung's first radio broadcast.

Lt. Colonel Untung appealed to all Army officers, non-commissioned officers and soldiers to be resolute and to act to eradicate completely the influence of the Council of Generals and its agents [kaki tangannya] in the Army. Power-mad Generals and officers who have neglected the lot of their men [anak buah] and who above the accumulated sufferings of their men [anak buah] have lived in luxury, led a gay life, insulted our women and wasted government funds, must be kicked out of the Army and punished accordingly. The Army is not for generals, but is the possession of all the soldiers of the Army who are loyal to the ideals of the revolution of August 1945.73

The anger toward the generals expressed in this statement has the same connotation as that of the pemuda which exploded twenty years earlier.

Wikana, who had been an anak mas (favorite pupil or protégé) of Sukarno, brought the meeting to an emotional climax by clearly implying that Sukarno was failing to live up to his role as bapak (patron or leader). ${ }^{74}$

Lieut. Col. Untung's statement declared clearly and precisely that the coup was directed against "Power-mad Generals and officers who have neglected the lot of their men [anak buah]." The difference, however, is found in the dazzling juxtaposition of the official armed forces' rankings and the personal bapak-anak buah relationships. The expectation behind the statement is that the generals of the Army should be and should act as bapak to all their lower-ranking soldiers whom they are to protect as their anak buah. In fact, however, the generals selected only a portion of them whom Lieut. Col. Untung named as the "agents [kaki tangan, Lit. feet and hands]" in contrast to the rightful name of "anak buah."

On the afternoon of October 1, 1965, the following statement was issued.

\footnotetext{
72Brian May, Indonesian Tragedy, p.99; Soeharto; Pikiran, Ucapan, dan Tindakan Saya, p. 130.

73“Selected Documents," Indonesia 1, p. 135.

${ }^{74}$ Anderson, Java in a Time of Revolution, p. 72.
} 
"Decision No. 2 concerning Demotion and Promotion in Rank"

(Text as read over the Djakarta radio at approximately 2:10 p.m. on October 1.)

1. As all authority in the State of the Republic of Indonesia on September 30, 1965, was taken over by the September 30th Movement and as its Commandant is an Officer with the rank of Lieutenant Colonel, all ranks and equivalent grades in the Armed Forces of the Republic of Indonesia above that of Lieutenant Colonel are herewith declared invalid.

All officers who were previously of a rank higher than Lieutenant Colonel must state their loyalty in written form to the Indonesian Revolution Council and only thereafter have they the right to use the rank of Lieutenant Colonel. Lieutenant Colonel is the highest rank in the Armed Forces of the State of the Republic of Indonesia. ${ }^{75}$

Instead of making himself a general, the Lieutenant Colonel is to remain a lieutenant colonel and all the officers senior to him are to come to the Revolutionary Council to state their loyalty.

This is equivalent to the Rengasdengklok kidnapping. Bapak is to be forced to come to the place of his anak buah. And yet the idea of making bapak subordinate to anak buah, by depriving him of his rank altogether, or by ranking him lower than Lieutenent Colonel, never occurred even in this statement. Even in a revolution an anak buah was only able to demand that his bapak live up to his role as bapak, or otherwise to finish him off. ${ }^{76}$ Once someone is a bapak, there is no way out, except by death.

2. Because the September 30th Movement is basically a movement of lower-ranking Soldiers, especially of Enlisted Men and NCO's it is herewith stated that all Enlisted Men and NCO's of all Armed Forces of the Republic of Indonesia who support the September 30th Movement are promoted to two grades above those they occupied before September 30, 1965.77

It was not only a rebellion within the bapak-anak buah relations which are inherently contained in the Indonesian Army as well as in all other organizations, but it was also an attempt to restructure the Army by approximating its inner structure to bapak-anak buah relations-flattening its hierarchical structure, or, if not, reducing it to just two ranks, Bapak and Anak Buah. That, in fact, had been more or less the ideal of the Indonesian Army since the days of the guerrilla war led by the legendary Sudirman. With this afternoon statement, however, all officers with a rank higher than Lieutenant Colonel would have little enthusiasm for supporting the coup-a fact which Major-General Soeharto shrewdly succeeded in capitalizing on to gain support. (He was in a position to recover the radio station by noon, but waited for more announcements to be broadcast.)

Now the new voice of Major-General Soeharto who skillfully suppressed the coup makes clear that by definition an anak buah can not possibly "kidnap" his bapak. An anak buah can only bring his bapak to safety. This is a way of saying that an anak buah can never rebel against his bapak, nor reverse the route-map. Eko's mother's privilege is to be secured linguistically. It is, therefore, only those who are outside this bapak-anak buah relationship who could kidnap Omar Dhani. Otherwise, it is a betrayal. The time of revolutionary

\footnotetext{
75"Selected Documents," Indonesia 1, p. 139.

${ }^{76}$ l owe this perception/point to Rudolf Mrazek.

77 "Selected Documents," Indonesia 1, p. 139.
} 
rhetoric is over. The possibility of revolution is to be eradicated from the language structure itself.

This also shows us that, as early as October 15, right after Soekarno's voice failed to establish the nature of the incident, long before the patient and outstanding soldier would eventually make himself the Second President of Indonesia, Soeharto's voice was already the one that defined the character of this event by establishing a new system of definition in language. The acts of taking someone somewhere thus acquired their new godfather, who would identify and give them names, and regulate the flow of Indonesian history. 